FILOLOGIJA 72, Zagreb 2019.

UDK 81'255.4 Zamanja, B. DOI https://dx.doi.org/10.21857/yvjrdcqq0y Izvorni znanstveni članak Rukopis primljen 25. III. 2019. Prihvaćen za tisak 1. VII. 2019.

Petra Matović

Odsjek za klasičnu filologiju

Filozofski fakultet

Sveučilište u Zagrebu

Ivana Lučića 3, HR-10000 Zagreb

psostari@ffzg.hr

Ana Mihaljević

Staroslavenski institut

Demetrova 11, HR-10000 Zagreb

amihaljevic@stin.hr

\title{
ZAMANJIN PRIJEVOD HESIODOVE TEOGONIJE
}

U radu se analizira Zamanjin prijevod Hesiodove Teogonije. Navode se okolnosti nastanka toga prijevoda, povezuje se Zamanjin odabir teksta sa značajkama vremena u kojemu je stvarao, a koje je izrazito sklono didaktičnim epovima, te se uočavaju utjecaji Zamanjina obrazovanja. Analizira se Zamanjin stav prema Hesiodu i iznose se podatci koje Zamanja navodi o grčkome pjesniku u predgovoru svojemu prijevodu. Uočavaju se glavni problemi pri prevođenju s grčkoga na latinski te se analiziraju i prikazuju Zamanjina prevoditeljska rješenja. Utvrđuju se Zamanjini uzori analizom pojedinih specifičnih leksema te analizom klauzula i njihovom usporedbom s tekstovima u bazi Musisque Deoque.

\section{Uvod}

Rad dvojice neraskidivo povezanih osamnaestostoljetnih pjesnika i prevoditelja, sugrađana i redovničke subraće Rajmunda Kunića i Bernarda Zamanje privlači sve veću pozornost filologa koji proučavaju njihov autorski i prevoditeljski opus. Posljednji je doprinos tomu istraživanju opsežna studija Irene Bratičević, koja donosi obilje novih biografskih podataka o Rajmundu Kuniću i detaljnije prikazuje okruženje u kojemu su on i Zamanja djelovali (Bratičević 2015). U proučavanju prevoditeljsko- 
ga rada Bernarda Zamanje dosad su obrađeni prijevodi Homerove Odiseje (Šonje 1975; Šoštarić 2013; Ćosić-Mrgan-Šoštarić 2016), Hesiodovih Poslova i dana (Bricko 2002b) te, u usporednoj analizi Kunićeva i Zamanjina prijevoda, Teokritove Idile (Bricko 2002a). Hesiodovo djelo Teogonija u Zamanjinoj latinskoj inačici također zaslužuje pozornost zbog opsega jer sadržava više od 1000 stihova te zbog svoje književne vrijednosti. ${ }^{1}$ Naposljetku, autor grčkoga izvornika važan je u povijesti zapadne književnosti: Hesiod je začetnik žanra genealoškoga i didaktičnoga pjesništva te, riječima Glena Mosta, »prvi pjesnik zapadne kulture čije nam je ime poznato« (Hesiod 2006:XVIII). Glavni je cilj ovoga rada kontekstualizirati Zamanjin prijevod Teogonije i navesti njegove osnovne prevoditeljske značajke. Ovaj je rad prilog traduktološkim istraživanjima hrvatske humanističke baštine, proučavanju recepcije grčkih autora u hrvatskoj kulturi te istraživanju hrvatske novolatinske književnosti općenito.

\section{Bernard Zamanja}

\section{1. Život i djela ${ }^{2}$}

Bernard Zamanja (Brno Džamanjić, Bernardus Zamagna) rođen je 9. studenoga 1735. u Dubrovniku. U rodnome je gradu pohađao isusovački kolegij. Kao darovit učenik, obrazovanje je nastavio na Rimskome kolegiju, središnjoj isusovačkoj obrazovnoj ustanovi, na kojemu su mu predavali njegovi stariji sugrađani Ruđer Bošković i Rajmund Kunić te drugi ugledni učenjaci poput Giuseppea Mazzolarija. Nakon ukidanja isusovačkoga reda Zamanja je još neko vrijeme u Italiji predavao grčki jezik i retoriku, a potom se vratio u Dubrovnik, u kojemu je vršio službu vikara Dubrovačke nadbiskupije i inspektora dubrovačkoga liceja. Umro je 20. travnja 1820. godine u rodnome gradu. Zamanjin opus, pisan isključivo na latinskome, može se podijeliti na dva dijela: autorska djela i prijevodi. U autorska djela ubrajaju se didaktične pjesme Echo (1764., drugo izdanje 1773.) i Navis aëria (1768., drugo izdanje 1784.), kojoj je priložena i zbirka

1 Westovo i Mostovo izdanje Teogonije sadržavaju po 1022 stiha (Hesiod 1966; Hesiod 2006), ali treba napomenuti da je broj stihova sporan (v. npr. Hesiod 2006:IL), a posljednja dva stiha Teogonije ujedno su i dva početna stiha Kataloga žena (npr. u Mostovu izdanju, Hesiod 2006:85). Katalog žena pripisivao se Hesiodu, ali najvjerojatnije nije njegovo djelo. Izdanje grčkoga teksta kojim se služio Zamanja ima 1021 stih (Hesiod 1701).

2 Zamanjini život i djela ukratko su prikazani prema natuknici u Hrvatskoj enciklopediji (http://www.enciklopedija.hr/Natuknica.aspx?ID=66791), Appendiniju (1830, 2016:486-488) i Bitzel (1997:14-27). O prijevodu Osmana više u predgovoru dostupnome u digitalnoj zbirci CroALa na http://www.ffzg.unizg.hr/klafil/croala/cgibin/getobject.pl?c.441:1:2.croala. 
Elegiarum monobiblos ad magnam Dei Matrem, heksametarske poslanice tiskane 1797. u Veneciji, prigodne elegije, idile, carmina, hendekasilabi, epigrami i govori, među kojima se nalazi i nadgrobni govor za Ruđera Boškovića pisan na zahtjev dubrovačkoga Senata. Mladenačko djelo De aucupio accipitris smatra se izgubljenim (više o njemu u Bitzel 1997:16). Drugi dio Zamanjina opusa čine prijevodi s grčkoga i hrvatskoga na latinski. S hrvatskoga je na latinski preveo Menčetićeva Radonju i trideset stihova iz devetoga pjevanja Gundulićeva Osmana. S grčkoga je na latinski preveo Homerovu Odiseju, Hesiodovu Teogoniju, Poslove i dane i Štit te bukolske pjesnike Teokrita, Biona i Mosha.

\subsection{Intelektualni i kulturni kontekst Zamanjina rada}

Zamanja je velik dio svojega života proveo $\mathrm{u}$ isusovačkim kolegijima, najprije kao učenik, a kasnije kao predavač. Isusovačko obrazovanje bilo je oblikovano dokumentom objavljenim 1599. godine pod nazivom Ratio atque Institutio Studiorum Societatis Iesu (u ovome se radu citira prema engleskomu prijevodu kao The Jesuit Ratio studiorum 1970), u kojemu je iznesen nastavni plan i program za svaku razinu obrazovanja. Prva tri dijela obrazovanja zvala su se gramatika, humanitas i retorika. Ona su činila studia inferiora, a filozofija i teologija činile su studia superiora. Za svaku od tih razina bili su propisani prikladna lektira i zadatci. Yasmin Haskell ističe da je glavni cilj isusovačkoga obrazovanja bio razviti sposobnost izražavanja (Haskell 2014a:785). Ovdje ćemo sažeto prikazati studia inferiora da dočaramo kako se ta sposobnost razvijala i prikažemo sustav u kojemu je Zamanja stasao. Gramatika latinskoga jezika učila se tri godine prema udžbeniku Manuela Álvaresa. Učitelji su morali, čim bi to bilo moguće, razgovarati s učenicima na latinskome (The Jesuit Ratio studiorum 1970:64). Najviši razred prvoga obrazovnog stupnja, tj. gramatike, čitao je Ciceronova pisma i spise De amicitia, De senectute, Paradoxa stoicorum, pročišćen izbor iz Tibula, Katula i Propercija, odabrane Vergilijeve ekloge i lakša pjevanja Georgika i Eneide. Na nastavi grčkoga čitali su se sv. Ivan Zlatousti, Agapet i Ezop. Učenici su napamet učili gramatička pravila, odlomke iz Cicerona i grčkih pisaca te su ih svakodnevno recitirali na nastavi (The Jesuit $R a-$ tio studiorum 1970:84-85). Na višim stupnjevima obrazovanja (humanitas i retorika) učenici su gotovo svaki dan morali predavati učitelju prozni sastavak na latinskome, dva puta tjedno u stihu, a jednom tjedno sastavak na grčkome (The Jesuit Ratio studiorum 1970:65). U dijelu obrazovanja nazvanome humanitas od rimskih pisaca čitali su se Ciceron (moralna filozofija i govori), Cezar, Salustije, Livije, Kurcije, Vergilije (osim nekih ekloga i četvrtoga pjevanja Eneide), odabrane Horacijeve ode te Soarezov priruč- 
nik De arte rhetorica. Od grčkih autora čitali su se lakši Isokratovi govori, sv. Ivan Zlatousti, sv. Bazilije, Platon, Sinesije, Plutarh, Fokilid, Teognid i dr. (The Jesuit Ratio studiorum 1970:80-81). Lektiru na sljedećoj razini isusovačkoga obrazovnog sustava, retorici, činila su Ciceronova govornička djela, Aristotelova Retorika i po potrebi Poetika (The Jesuit Ratio studiorum 1970:72-73), Demosten, Platon, Tukidid, Homer, Hesiod, Pindar, sv. Grgur iz Nazijanza, sv. Bazilije i sv. Ivan Zlatousti (The Jesuit Ratio studiorum 1970:77). Jednom mjesečno učenici bi pisali govor ili pjesmu na latinskome ili grčkome »osobito uzvišena stila«, a svakoga drugog mjeseca za posebne prilike istaknuli bi se njihovi najuspješniji stihovi (The Jesuit Ratio studiorum 1970:78). Haskell primjećuje da u isusovačkome kurikulu Vergilije nije bio toliko sveprisutan kao pjesnički uzor kao što je Ciceron bio prozni iako se, naravno, ne može osporiti važnost Vergilijeva utjecaja na isusovačko književno stvaralaštvo (za detaljniju analizu v. Haskell 2010:207).

Osim u kontekstu isusovačkoga obrazovanja, Zamanjin autorski i prevoditeljski rad treba gledati i u kontekstu književnopovijesnoga razdoblja kojemu pripada, tj. neoklasicizma. Zamanja je, poput Kunića i Boškovića, bio član talijanske književne akademije Accademia dell' Arcadia ili Accademia degli Arcadi, osnovane 1690. godine u Rimu u čast švedske kraljice Kristine (u. 1689.), koja je posljednja desetljeća života provela u Vječnome Gradu okružena umjetnicima i intelektualcima. ${ }^{3}$ Članovi Akademije, među kojima je bilo i žena, bili su istaknuti građani posvećeni promicanju neoklasicističkih umjetničkih načela i zatiranju baroknoga ukusa. Nadahnuti antičkim bukolskim pjesništvom, u kojemu je bio opjevan idealiziran život pastira u pokrajini Arkadiji, za simbol su izabrali Panovu sviralu, na sastancima su se rado odijevali u pastirsku odjeću, a svaki je član imao pastirski pseudonim. ${ }^{4}$ Čitali su svoje radove i natjecali se u svojoj pjesničkoj inačici Olimpijskih igara. ${ }^{5}$ Svoju su poeziju, spjevanu u skladu s neoklasi-

3 Kratak prikaz prema Dixon (2006:19-31), Irmscher (2006:212-213), Bratičević (2015:164-166). Irmscher sažeto prikazuje i Arkadiju u antičko doba te Arkadiju kao književnu inspiraciju i temu u različitim književnopovijesnim razdobljima (2006). Snell govori o konceptu Arkadije u Vergilijevim Eklogama: između ostaloga o razlozima zbog kojih Vergilije nije od Teokrita, začetnika žanra, preuzeo Siciliju kao idealno pastirsko mjesto te o Arkadiji kao mjestu susreta mitskoga i stvarnoga (2011).

4 Ti su pseudonimi imali dva dijela: prvi se dio u ranijemu razdoblju Akademije uzimao iz antičke bukolske poezije, dok se u kasnijemu mogao i izmisliti, a drugi se dio uvijek izvodio od nekoga toponima (Dixon 2006:20-21). U pohvalnoj ocjeni (approbatio) u izdanju Jeke kao Zamanjin pastirski pseudonim navodi se Triphilus Cephisides [sic] (Zamanja-Kunić 1764:X), čiji je drugi dio izveden od hidronima Kefis (grč.

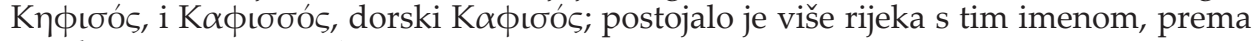
natuknici na Logeionu).

5 Više o igrama i njihovoj ulozi u očuvanju identiteta Akademije v. Tatti (2012). 
cističkim ukusom, i objavljivali. ${ }^{6}$ Kaminski navodi pet glavnih načela neoklasicističke estetike:

»1. oponašanje je temelj umjetničkoga stvaranja

2. postoje >pravila< kojima se umjetnik vodi

3. genij se mora pokoriti jarmu >umjetnosti<

4. doličnost je potrebna u svim aspektima djela

5. umjetnost mora istovremeno podučavati i pružati užitak« (2007:58).

Svaki je autor morao neprestano imati pred očima profinjenu aristokratsku kršćansku publiku za koju je pisao (Kaminski 2007:60). Ti su stavovi bili u uskoj vezi s prevoditeljskim tehnikama toga doba. David Movrin u svojoj studiji o povijesti prevođenja na Zapadu navodi istraživanja koja pokazuju da su prijevodi presudno utjecali na oblikovanje ukusa, a ne obrnuto (2010:101). U praksi je to značilo da su prevoditelji mogli sami procijeniti koje su, prema njihovu mišljenju, mane teksta $\mathrm{i}$ ispraviti ih prema nahođenju: izbacivanjem, dodavanjem, upotpunjavanjem, tumačenjem i komentiranjem (Movrin 2010:102). Neoklasicizam je doba u kojemu "prevodioci više ne pokušavaju s poštovanjem otkrivati što stvarno piše u originalu, već suvereno odlučuju što bi u njemu moralo pisati« (Movrin 2010:105). ${ }^{7}$ Smatramo vjerojatnim da je neoklasicistička estetika kakvu je promovirala Accademia dell' Arcadia ostavila traga na Zamanji, pa u završnome dijelu rada određujemo koliko je Zamanjin rad na Teogoniji usklađen s estetskim načelima koja je naveo Kaminski te uklapa li se Zamanja u sliku prevoditelja kakvoga opisuje Movrin.

\subsection{Zamanjini prijevodi s grčkoga na latinski}

Poput svojega učitelja Kunića, koji je preveo Ilijadu i neke Teokritove idile, Zamanja je u odabiru grčkih tekstova pokazivao osobitu naklonost prema arhajskoj epici (Homer, Hesiod) i helenističkomu bukolskom pjesništvu (Teokrit, Bion, Mosho). Odabir autora može se dovesti u vezu s ukusom tzv. galantnoga stoljeća. Zanimanje za Homera u neoklasicizmu izraženije je nego u renesansi, ne samo u književnosti (v. npr. Sowerby 2006:228-336), nego i u likovnoj umjetnosti (Wiebenson 1964). Zamanjin izbor Hesioda, prvoga didaktičnog pjesnika, također ne iznenađuje u vrijeme

Opjevao ih je i Ruđer Bošković u Eklogi, tiskanoj u Rimu 1753. i dostupnoj u zbirci CroALa (http://croala.ffzg.unizg.hr/cgi-bin/getobject.pl?c.363:1.croala.3838) te u Digitalnim zbirkama Nacionalne i sveučilišne knjižnice u Zagrebu (https://digitalna.nsk.hr/ $\mathrm{pb} /$ ?object=info\&id=10835).

6 O zbirkama njihove poezije v. Bratičević (2015:166).

7 Movrin donosi i niz ilustrativnih primjera (Movrin 2010). 
kad didaktično pjesništvo doživljava svoj labuđi pjev. Kao što je već navedeno, oba grčka epičara nalazila su se na popisu isusovačke lektire u sklopu programa retorike. Naposljetku, sklonost bukolskomu pjesništvu mogla je potaknuti i Accademia dell' Arcadia, koja je bila nadahnuta pastoralom.

Otprilike se može ustanoviti redoslijed kojim je Zamanja prevodio grčke autore. U predgovoru svojemu prijevodu Hesiodova Śtita Zamanja sam kaže da se toga djela prihvatio nakon prevođenja Odiseje (Zamanja 1776:III-IV). U predgovoru izdanja iz 1785., u kojemu su sabrana sva tri Hesiodova djela u latinskome prijevodu, Zamanja navodi da je prvo preveo Štit, potom Poslove i dane, a na kraju Teogoniju (Zamanja 1785:I). Taj redoslijed potvrđuje i činjenica da su Štit i Poslovi i dani objavljeni pet godina ranije, 1780. u Milanu (Zamanja 1780), a samostalno izdanje Štita još ranije, u Sieni 1776. (Zamanja 1776). Kako navodi u predgovoru samostalnomu izdanju Štita, iako je prijevod Homera završio prije toga djela, na nagovor izdavača odlučio je pričekati s objavljivanjem Odiseje (Zamanja 1776:IIIIV). U tome predgovoru spominje da je već preveo Biona i Mosha (Zamanja 1776:IV). Prvo izdanje Odiseje izišlo je 1777. godine. Prijevodi Teokrita, Biona i Mosha prvi su put tiskani 1784. godine, a potom još 1788. i 1792. Teokrit bi, ako ćemo vjerovati Zamanjinim riječima, tj. činjenici da ga ranije ne spominje, svakako bio zadnji pisac kojega je prevodio s grčkoga na latinski. Dakle, redoslijed je nastanka Zamanjinih prijevoda: Bion, Mosho, Odiseja, Štit, Poslovi i dani, Teogonija, Teokrit. ${ }^{8}$

Što se tiče izdanja Zamanjina prijevoda Teogonije, valja spomenuti da je iste godine objavljeno jednojezično (Zamanja 1785) i dvojezično izdanje (Hesiod-Zamanja 1785). U dvojezičnome se izdanju na stranicama 5-16 nalazi i heksametarska posveta Ferdinandu Austrijskomu, bratu Petra Leopolda kojemu je Zamanja posvetio prijevod Odiseje. U posveti je vidljiv Vergilijev utjecaj, osobito u početnim stihovima u kojima Zamanja oponaša početak Eneide. Zamanja je prijevod popratio opsežnim komentarom u kojemu interpretira odabrane odlomke, objašnjava neke izraze (toponime, teonime, epitete), navodi antičke izvore koji govore o Hesiodu (npr. Lukijan) i koje stilski i sadržajno uspoređuje s Hesiodom (npr. Homera, odnosno Ovidija) te u kojemu povremeno polemizira s ranijim prevoditeljima i komentatorima (npr. Le Clercom i njegovim feničkim etimologijama), a ni sam Hesiod nije pošteđen kritike pedantnoga isusovca (između ostaloga jer brka teogoniju s kozmogonijom).

U analizi Zamanjinih prijevoda Teokrita već je primijećeno da autor

8 Uz napomenu da za prva tri nije sasvim jasan redoslijed. 
povremeno nastoji uljepšati i pročistiti izvornik, tipično za njegovo doba, iako je to kod njega mnogo manje izraženo nego u njegova učitelja Kunića, koji se nije ustručavao nezgodna mjesta sasvim izbaciti (Bricko 2002a). Također, primjetan je utjecaj rimskih pjesnika, osobito onih zlatnoga doba, što je očekivano zbog isusovačkoga kurikula i neoklasicističke poetike, koju je promicala Accademia dell' Arcadia (Bricko 2002a, 2002b; Ćosić-Mrgan-Šoštarić 2016).

\section{Hesiodi Ascraei Deorum generatio}

\subsection{Hesiod: djelo i recepcija}

Grčki autor Hesiod najvjerojatnije je živio i stvarao u razdoblju između 750. i 600. g. pr. Kr. Njegovim se djelima smatraju epovi Teogonija i Poslovi i dani, dok je autorstvo Heraklova štita upitno (v. npr. Woodard 2009:84). U novije vrijeme sve veću pozornost privlače poveznice između Hesioda i bliskoistočne književnosti (v. npr. Woodard 2009). Postoje sumnje povezane s time je li Hesiod, kao i Homer, postojao te jesu li tekstovi koji se njemu pripisuju jedinstveni ili su nastali kasnije kompiliranjem usmenih dijelova (o toj raspravi v. npr. Nelson 2005). Unatoč tim sumnjama riječ je o prvome autoru u grčkoj književnosti koji u svojim djelima iznosi podatke o sebi - između ostaloga da mrzi svoj rodni grad Askru, da ima brata i oca te da je sudjelovao u pjesničkome natjecanju (Schlegel 2006:1-10). Hesiodovo djelo smatra se, uz Homera, jednim od početaka europske književne tradicije, ali za razliku od Homera njegov je identitet jasniji jer sam navodi svoje ime.

Hesiod se smatra začetnikom didaktičnoga epa u antičkoj književnosti u prvome redu zbog svojega djela Poslovi i dani. Didaktičnost je ono što se često ističe kao razlika između Hesioda i Homera, također velikana grčke epike (Koning 2010:341). S obzirom na to da je riječ o dvama velikim i važnim autorima koji stoje na početcima antičke književnosti i pišu epske tekstove, ne čudi da su u povijesti književnosti često bili uspoređivani. $\mathrm{Na}$ tjecanje Homera i Hesioda djelo je nepoznatoga autora u kojemu je prikazano pjesničko nadmetanje dvojice pjesnika. Prema mišljenju publike nagradu je zaslužio Homer, ali kralj ju je ipak dodijelio Hesiodu »uz objašnjenje da je pravo da pobijedi onaj koji poziva na poljodjelstvo i mir, a ne onaj koji pripovijeda o ratu i pokoljima« (Boj žaba i miševa, Natjecanje Homera $i$ Hesioda 2004:81). ${ }^{9}$ U antičkoj književnosti nije uvijek bilo jasno kako definirati Hesiodov stil i žanr. Tek je u aleksandrijskome krugu Hesiod jasnije

9 Više o Natjecanju Homera i Hesioda, osobito o problemu datacije, piše Koning (2010:239-268). 
određen kao pjesnik zbog želje aleksandrijskih filologa da naglase suprotstavljanje normi i Homeru (Koning 2010:342-343), ali se u literaturi ipak često ističe da je Hesiod i usprkos tomu znatno utjecao na antičko pjesništvo. Platon, premda vrlo skeptičan prema pjesnicima, hvali Hesioda (Rep. 466b, 468e, 546e), koji mu je draži od Homera (Nelson 2005:330). Na Platona osobito utječe Hesiodova priča o različitim dobima u ljudskoj povijesti, tj. priča o propasti čovjeka od zlatnoga do željeznoga doba (Schlegel 2006:9). Hesiodov utjecaj na Platona spominje i sam Zamanja u predgovoru svojemu prijevodu Teogonije (1785:XIV). Smatra se da su se svi kasniji grčki i rimski autori didaktičnih spjevova ugledali u Hesioda. Koning uočava zanimanje i za reakciju na Hesioda već kod predsokratovaca Ksenofana, Heraklita, Parmenida i Empedokla te pjesnika Pindara (2010:189_ 234, 310-316). Slavna je izjava grčkoga povjesničara Herodota (5. st. pr. Kr.) da su Homer i Hesiod pjesnici koji su naučili Grke o bogovima (Herodot 2,53). Hesiod je općenito važan izvor za poznavanje grčke mitologije (više u Dowden 2011/2014, koji obrađuje i kasnije mitografe te usputno i njihov odnos prema Homeru i Hesiodu). Naposljetku, svi su se rimski didaktičari također ugledali u Hesioda. ${ }^{10}$ Hesiodov je utjecaj osobito vidljiv u Vergilijevim i Lukrecijevim didaktičnim epovima. Teme iz Hesiodove Teogonije vrlo su slične temama u petome pjevanju Lukrecijeva epa De rerum natura i prvome pjevanju Ovidijevih Metamorfoza. Hesiod je utjecao i na druge srodne žanrove. U šestome pjevanju Eneide Vergilije u Silenova usta stavlja kombinaciju Hesiodovih i Lukrecijevih riječi (Aen. 6, 31). U svojim djelima Hesioda spominju i hvale i Dionizije Halikarnašanin i Velej Paterkul, a Kvintilijan ga ne cijeni kao Homera, ali ga također smatra korisnim štivom.

I u renesansno doba postoji veliko zanimanje za Hesioda. Krajem 15. st. objavljeni su heksametarski prijevodi Hesiodovih djela iz pera dvojice talijanskih humanista: Niccolò della Valle preveo je Poslove $i$ dane, a Bonino Mombrizio Teogoniju (Hesiodi Ascraei Georgica, Hesiodi Theogonia per Boninum Mombritium Mediolanensem). Od hrvatskih latinista Hesioda je prevodio i Matija Grbić Ilirik (Grbac, Matthias Garbitius Illyricus), koji je 1559. godine objavio prozni prijevod Poslova $i$ dana poprativši ga opsežnim komentarom (Hesiodi opera et dies).

\section{2. Žanrovsko određenje Teogonije}

Teogonija se često definira kao didaktični i genealoški ep, međutim, njegovu pripadnost žanru didaktičnoga pjesništva neki autori osporavaju. Toohey didaktično pjesništvo definira kao epski tekst iz kojega progova-

\footnotetext{
10 Recepcija Hesioda u starome Rimu sažeto je prikazana prema Rosati (2009).
} 
ra jedan autorski glas koji je usmjeren jednomu imenovanom ili neimenovanom primatelju (1996:4). To je ozbiljni žanr kojemu je glavni cilj poučiti. Često sadržava detaljne i tehničke opise uz mnoštvo primjera te mitološke teme. Tipičan je stih takvoga pjesništva u antici heksametar (s iznimkom Ovidijeva Ljubavnoga umijeća i Lijekova od ljubavi). Hesiod se smatra ocem te vrste pjesništva. Kad govori o žanrovskome određenju Teogonije, Toohey smatra da nije riječ o didaktičnomu pjesništvu. Prema njegovu mišljenju Teogonija ne zadovoljava kriterije koji određuju didaktično pjesništvo jer tekst nije usmjeren na primatelja, tj. nije prisutan učenik kojega se poučava, a izostanak drugoga lica isključuje i prisutnost implicitnoga primatelja kojega bi tekst trebao poučiti (Toohey 1996:21). U Teogoniji je uputa i poučavanje neizravno. Međutim, iako prema Tooheyu ne zadovoljava formalne kriterije da bi je se definiralo kao didaktični ep, Teogonija je zasigurno bila važan izvor za proučavanje i poučavanje antičke mitologije; kao što je već spomenuto, tu je važnost uočio već i otac povijesti Herodot.

Didaktično je pjesništvo doživjelo osobit procvat upravo u 18. st., stoljeću u kojemu je živio i stvarao Zamanja, zato što je didaktičnost jedna od značajka prosvjetiteljstva. Zanimanje za didaktičnu književnost u 18. stoljeću širi se i na novolatinsku književnost (Korenjak 2016:96-97; o posebnome zanimanju koje su isusovci pokazivali za taj žanr u 17. i 18. st. v. Haskell 2003, sažeto u Haskell 2014b:36-38). I u hrvatskoj se književnosti 18. st. šire prosvjetiteljske ideje koje se osobito ogledaju u djelima Filipa Grabovca, Matije Antuna Relkovića i Andrije Kačića Miošića. I Grabovčev Cvit razgovora naroda i jezika iliričkoga aliti rvackoga i Relkovićev Satir iliti divji čovik i Kačić-Miošićev Razgovor ugodni naroda slovinskoga namijenjeni su neukomu čitatelju kojega bi takav tekst trebao poučiti. U predgovoru prvomu izdanju Razgovora ugodnoga Kačić Miošić, obraćajući se bratu štiocu, otkriva primarnu namjenu takvih tekstova: poučiti neukoga seljaka slavnoj povijesti slavenskih naroda. Cilj je Grabovčeva Cvita također poučiti seljaka povijesti, a u Satiru Relkovićeva je namjera poučiti neukoga slavonskog seljaka da se odmakne od loših turskih skula i da iskoristi ljepotu i plodnost zemlje na kojoj živi. ${ }^{11}$ Prevođenje djela kao što je Teogonija tako se izrazito uklapa u duh razdoblja i ne čudi da je Zamanja posegnuo upravo za Hesiodovim djelima. Međutim, treba ipak naglasiti da je namjena Zamanjina djela bila drukčija. S obzirom na to da je tekst na latinskome, nije ciljao na istu publiku kao Kačić Miošić, Relković i Grabovac koji su se obraćali isključivo hrvatskomu čitateljstvu i slušateljstvu, nego na međunarodnu intelektualnu zajednicu kojoj je latinski još uvijek lingua franca. Nadalje, njegov cilj nije bio poučiti neuke seljake i slaviti povijest i način života svoje-

11 V. npr. Pavličić 1987; Dukić 1998, 2002, 2003, 2007; Fališevac 2003. 
ga naroda, nego približiti suvremenicima stilizirano djelo antičkoga autora te pokazati da postoje djela koja mogu biti izvor pouke čak i za već obrazovanu publiku istančanoga ukusa.

\section{Zamanjin prijevod Hesiodove Teogonije}

\subsection{Zamanjin predgovor prijevodu}

Zamanjinu prijevodu prethodi opširan predgovor na latinskome. ${ }^{12} \mathrm{U}$ predgovoru Zamanja navodi da se prihvatio prijevoda Hesiodove Teogonije nakon što je završio prevođenje Homerove Odiseje i nakon što je preveo Hesiodov Štit i Poslove $i$ dane. Prijevod Teogonije objavljuje uz grčke stihove kako bi se njegov prijevod lako mogao usporediti s grčkim. Pritom spominje da se služio izdanjem koje naziva Graeviana editio. ${ }^{13}$ Navodi da zna da su i prije njega Hesiodovi tekstovi bili prevedeni na latinski, ali da je on pri prevođenju nastojao oponašati Vergilijev stil, dakle, sam ističe da mu je Vergilije glavni uzor. U predgovoru Zamanja donosi i podatke o Hesiodovu životu, o čemu navodi da nije pisao kad je objavio Poslove $i$ dane $\mathrm{i}$ Štit te o samoj Teogoniji. Zamanja, dakle, ne dvoji o Hesiodovu postojanju, samo navodi da njegovo točno rodno mjesto nije sigurno. Navodi osnovne podatke o njegovu životu, legende o smrti te raspravu o godinama kad je živio i o tome je li prethodio Homeru ili ne. Zamanja je vrlo upućen u raspravu o tome kad je Hesiod živio i iznosi različita mišljenja, detaljno ih razlaže i argumentira te opsežno prikazuje stavove različitih antičkih autora. Zamanja navodi da je Hesiod i $u$ antici bio cijenjen autor te navodi mišljenja Dionizija Halikarnašanina i Veleja Paterkula. Iznosi i stav Marka Fabija Kvintilijana, koji kaže da se Hesiod rijetko ističe i zaostaje za Homerom, ali donosi mnoge korisne moralne primjere, a njegov je stil opisan kao levis/lenis te mu Kvintilijan daje nagradu u srednjemu stilu. Pritom Zamanja parafrazira Kvintilijanove riječi, uglavnom se vjerno držeći izvornika uz poneku promjenu u redu riječi te bira sinonimne i etimološki slične riječi za opis njegova stila (lenitas 'blagost' u odnosu na levitas 'lakoća', expositionis 'razlaganje, razvijanje, opis' umjesto compositionis 'sasta-

12 Isti je predgovor tiskan u jednojezičnome izdanju teksta na stranicama I-XXXV (Zamanja 1785) i dvojezičnome izdanju na stranicama I-XXXV koje se nalaze između posvete Ferdinandu Austrijskomu i grčkoga teksta (Hesiod-Zamanja 1785). Dvojezično izdanje dostupno je na stranicama Austrijske nacionalne knjižnice (Österreichische Nationalbibliothek) http://digital.onb.ac.at/OnbViewer/viewer.faces?doc=ABO_\%2BZ176046706.

13 Riječje o izdanju u kojemu je grčki tekst priredio Johann Georg Graevius, a prijevod Teogonije Jean Le Clerc (Joannes Clericus), uz bilješke iz pera nekolicine drugih autora uključujući Le Clerca (Hesiod 1701). 
vak, spoj', mediocri 'srednji, umjeren' umjesto medio 'srednji'). Zamanja navodi da se nakon Hesiodove smrti filozof Zenon bavio njegovim djelima. Činjenicu da je Hesiod bio velik i važan autor Zamanja potkrepljuje činjenicom da je u mnogim gradovima dobio spomenike te ih navodi slijedeći Pauzaniju. Zamanja iznosi stav da Teogonija nije neobičan tekst u grčkoj književnosti jer su postojale i ranije teogonije, npr. Orfejeva, no ističe veliku vrijednost upravo Hesiodove koja je sačuvana do njegovih dana. Ipak, Hesiod nije autor bez mane: Zamanja mu predbacuje da je u Teogoniji pomiješao razne izvore i mitološke tradicije (tračku, feničku, egipatsku, kaldejsku), što otežava posao prevoditeljima i tumačima, od antičkih vremena do novijih proučavatelja grčke mitologije (npr. Daniëla Heinsa, Samuela Bocharta, Pierrea Daniela Hueta i već spomenutoga Le Clerca), koji nisu uvijek znali ponuditi prihvatljiva objašnjenja pojedinih mjesta, nego su smišljali nategnute etimologije i interpretacije. Zamanja smatra Teogoniju izvorom informacija za četiri velike teme: nastanak svijeta, političko i društveno uređenje, religiju i drevnu povijest do Trojanskoga rata. Zamanja detaljno prikazuje Hesiodove stavove o nastanku svijeta. Iznosi i stav da Hesiod nije nužno vjerovao u bogove koje je opjevao u Teogoniji, ali da je smatrao religiju važnim elementom društvene kohezije. Predgovor $u$ cjelini pokazuje Zamanjino izvrsno poznavanje Hesiodova opusa i izvora koji govore o njemu te upućenost u literaturu o grčkoj mitologiji kakvu možda ne bismo očekivali od isusovca.

Svoj prevoditeljski credo Zamanja je detaljnije prikazao na drugome mjestu, u raspravi Ratio operis, objavljenoj uz prijevod Odiseje, u kojoj se izjašnjava protiv »sekte« doslovnih prevoditelja i navodi Cicerona kao uzornoga prevoditelja. Iako ne iznosi prevoditeljska načela detaljno poput svojega učitelja Kunića u raspravi Operis ratio uz prijevod Ilijade, Zamanja jasno daje do znanja da se trudio postići i ljepotu i vjernost u prijevodu, pri čemu kao stilski uzor ističe Vergilija (Zamanja 1777:XIX-XXXV).

\subsection{Usporedba grčkoga izvornika i latinskoga prijevoda}

Na odabranome ulomku s početka epa prikazat ćemo Zamanjin prevoditeljski stil s naglaskom na gramatičke preoblike te se pojedinačno osvrnuti na neke prevoditeljske postupke (sažimanje, proširivanje) i izazove u prevođenju s grčkoga na latinski (participi, čestice, složenice itd.). Latinski primjeri citiraju se prema izdanju iz 1785. 
Teogonija 1-8.

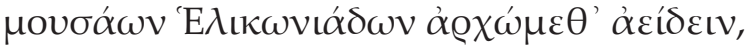

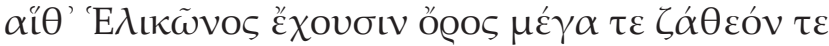

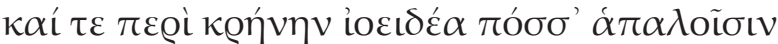

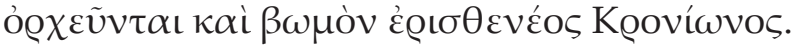

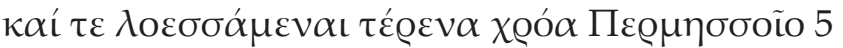

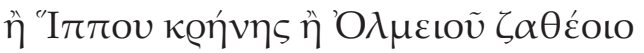

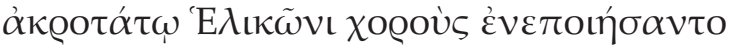

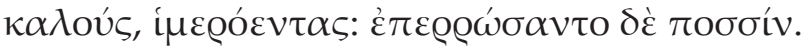

Principium nostri Musae sint carminis, alta

Quae iuga concelebrant, sacras Heliconis et umbras,

Pernicique solum plaudunt pede caerula propter

Stagna Iovisque aram; tum lotae mollia membra

Permessove, Olmiove, aut fonte Hippocrenes 5

Pegaseo, aonii divino in vertice montis

Inter se dulces gaudent agitare choreas

Ingentem edentes sonitum procul.

Adhortativni konjunktiv $\alpha \varrho \chi \omega ́ \mu \varepsilon \theta^{\prime}$ iz prvoga stiha preoblikovan je $\mathrm{u}$ imenski predikat principium sint. Predikat je prebačen iz prvoga u treće lice množine. Infinitivna dopuna predikatu $\alpha \varepsilon \varepsilon^{\prime} \delta \varepsilon \iota v$ pretvorena je u imenicu carminis, koja je u genitivu i ovisi o riječi principium. U latinskome prije vodu Muze su postale subjekt rečenice, ali su pomaknute s početnoga mjesta u stihu. Iako je gramatički preoblikovao dijelove toga stiha, Zamanja je zadržao njihova značenja koja je drukčije izrazio. U petome stihu sastavni veznik $\kappa \alpha i ́ ~ \tau \varepsilon$ pretvara $u$ vremenski prilog tum. U šestome stihu kod Hesioda dvaput nalazimo rastavni veznik $\eta$. Zamanja umjesto njega upotrebljava dva različita rastavna veznika -ve i aut. U sedmome stihu predi-

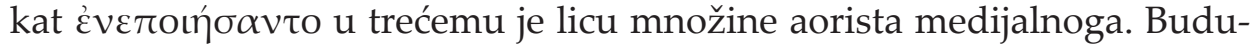
ći da u latinskome od stanja postoje samo aktiv i pasiv, Zamanja uz predikat $\mathrm{u}$ aktivu dodaje priložnu oznaku inter se, kojom nadoknađuje nedostatak medija. Predikat je prebačen iz aorista u prezent: gaudent agitare, pri čemu je u latinskome tekstu predikat semantički nepovezan s izvornikom, ali njegova dopuna infinitiv agitare može imati uz sebe objekt choreas, koji

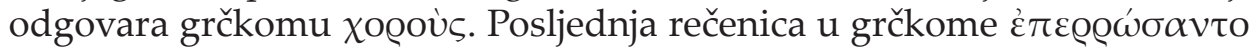

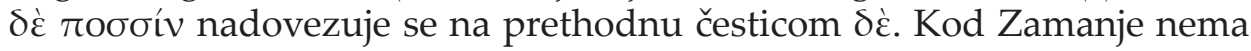
čestica, a rečenica je pretvorena u particip edentes dopunjen prilogom pro- 
cul i objektom ingentem sonitum. Značenjske veze između grčkoga izvornika i latinskoga prijevoda u ovoj rečenici nema, ona samo dopunjava ono što je već rečeno te si je pri njezinu prevođenju Zamanja dopustio priličnu slobodu.

Oronim Helikon pojavljuje se u ovome odlomku dva puta (tri ako računamo pridjev 'E $\lambda \iota \kappa \omega v \iota \alpha ́ \delta \omega v$, epitet Muza). Zamanja je odlučio izbjeći ponavljanje, pa kod njega samo u drugome stihu nalazimo Heliconis, dok se $\mathrm{u}$ šestome izrazio opisno aonii montis. Broj je stihova u tim dvama odlomcima jednak, no to nije uvijek slučaj u Zamanjinu prijevodu u odnosu na Hesioda, što ćemo prikazati u odlomcima koji slijede. Na temelju ovoga odlomka vidljivo je da se Zamanja katkad udaljava u formi, tj. gramatičkim oblicima da bi prilagodio Hesioda latinskomu jeziku, a značenje originala prenosi na različite načine.

\subsection{Sažimanje i proširivanje}

Zamanjin tekst sadržava 1130 redaka, dakle premašuje original za otprilike desetinu. Iako se Zamanja proširivanjem izvornika očito služio znatno više nego skraćivanjem, mogu se naći primjeri sažimanja origina-

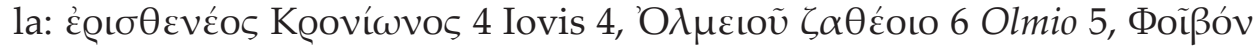

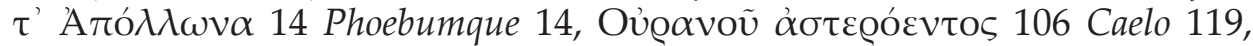

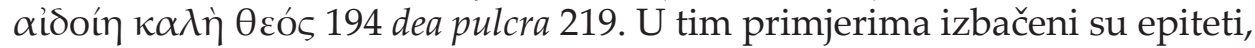
osim u primjeru Phoebumque, gdje je u prijevodu zadržan pridjevak boga Apolona, a izbačeno njegovo ime. Još jedan primjer kraćenja nalazimo $u$

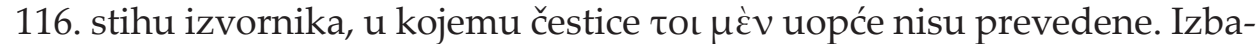
civanje epiteta i čestica može se objasniti nedostatkom istovrijednice u latinskome rječniku. Epiteti su vrlo često bili složenice poput gore navede-

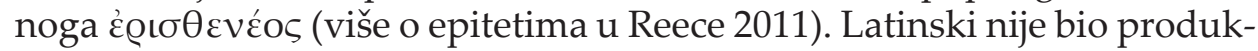
tivan u tvorbi složenica poput grčkoga te su one očekivano izazov prevoditelju i često ih se ne može nadomjestiti jednom riječju (više o latinskim složenicama u Fruyt 2002; o prevođenju složenica više će riječi biti kasnije). Također, epiteti se mogu smatrati nefunkcionalnim tipom homerske formule jer ih se može izostaviti iz pripovijedanja, za razliku od funkcionalnih formula koje su nužne u usmenoj izvedbi epske pjesme (Bowra 1952:222). Začetnik istraživanja epskih formula Milman Parry smatrao je da je kod epiteta najvažnije da odgovaraju metričkim zahtjevima, a ne da budu usklađeni s kontekstom (sažet prikaz Reece 2011:257-258). Možda ih je i Zamanja na nekim mjestima smatrao nepotrebnima ili neusklađeni-

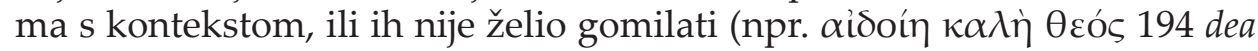
pulcra 219). 
Kao što je vidljivo iz većega broja stihova u odnosu na izvornik, brojniji

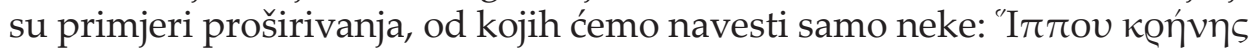

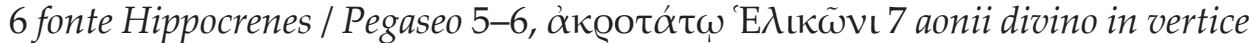

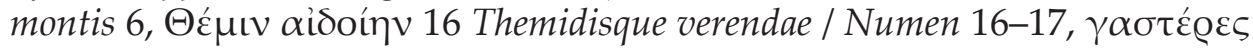

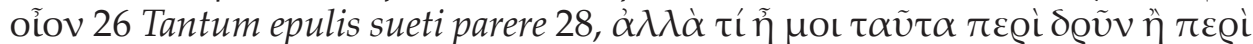

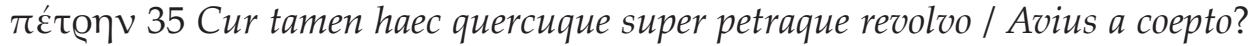

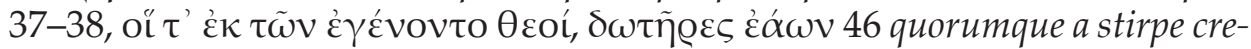
atos / Novimus egregios post prima exordia divos / Cunctorum auctores servatoresque bonorum 48-50, ô $\delta$ ' ő $\lambda \beta เ$ lix sed et ille, Camoenae / Quem meritum donis augent, et amore tuentur 106-

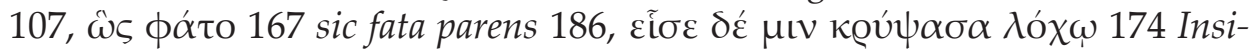
diasque parans occulta in sede locavit / Audacem gnatum 193-194, Фó@кvї $\delta$

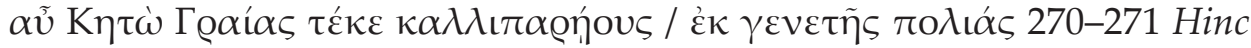
Graeas Phorcyni enixa est candida Ceto / Canitie insignes aetatis vere sub ipso 304-305.

U nekima od tih primjera Zamanja je želio objasniti Hesiodove zakuča-

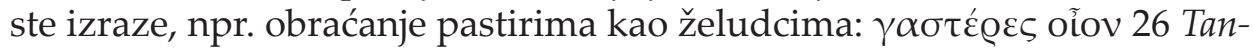

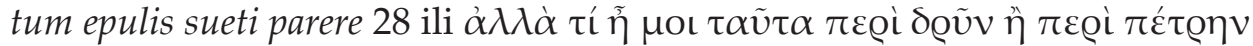
35 Cur tamen haec quercuque super petraque revolvo / Avius a coepto? 37-38, a povremeno je smatrao opravdanim dati dodatne informacije: "I $\pi \pi 0 v$

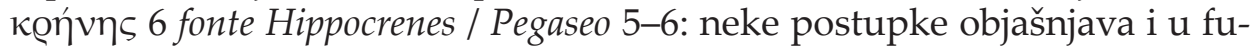
snotama. ${ }^{14}$ Neka proširenja ne mijenjaju značenje: $\Theta \varepsilon ́ \mu t v$ aỉoónv 16 Themidisque verendae / Numen 16-17. Možemo pretpostaviti da su neka proširenja motivirana ugledanjem na antičke pisce, čije je riječi uklopio u svoj

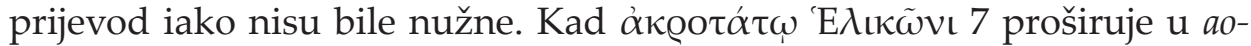
nii divino in vertice montis 6, Zamanja se koristi klauzulom vertice montis, koja se nalazi kod nekoliko rimskih pjesnika: Cicerona, Katula, Vergilija, Ovidija, Juvenka i dr. Najviše puta, čak devet, upotrijebio ju je Silije Italik.

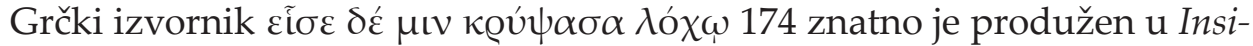
diasque parans occulta in sede locavit / Audacem gnatum 193-194. Početak stiha Insidiasque parans mogao bi biti posuđen od Koripa (Insidiasque parat. nam Mauri tempore cuncto Ioh. 6, 181), dok se klauzula sede locavit pojavljuje kod Vergilija, Valerija Flaka, Klaudijana, Paulina iz Nole, Koripa, Venancija Fortunata i drugih. ${ }^{15}$

14 Za modernu analizu i tumačenja 26. stiha Teogonije v. Katz-Volk (2000), a za 35. stih v. Westovu analizu (Hesiod 1966:167-169).

15 Za pretraživanje antičkoga pjesništva upotrijebljena je digitalna zbirka Musisque Deoque. 


\subsection{Neki jezični izazovi u prevođenju s grčkoga na latinski}

Svi su se prevoditelji s grčkoga na latinski morali suočiti s gramatičkim razlikama između tih dvaju jezika. Te su strukturne i gramatičke razlike između jezika izvornika i ciljnoga jezika velik prevoditeljski problem jer se prevoditelj u tim slučajevima ne može poslužiti formalnim korespondentom kao prijevodnom istovrijednicom. Prevoditeljskim problemom mogu postati razlike u latinskome i grčkome glagolskom sustavu: grčki ima perfekt i aorist, dok latinski ima samo perfekt; grčki ima tri stanja: aktiv, medij i pasiv, latinski samo aktiv i pasiv. Grčki ima i glagolske participe svih osnova, s time da se medijalni i pasivni oblici razlikuju samo u aoristu i futuru. Za razliku od razvijenoga sustava participa u grčkome latinski ima samo particip prezenta aktivnoga, particip perfekta pasivnoga i particip futura aktivnoga. Grčki se participi stoga često prevode zavisnim rečenicama, npr. odnosnom: 'O $\lambda \dot{\mu} \mu \pi \iota \alpha \delta \omega \mu \alpha \tau$ ' ع́ $\chi 0 v \sigma \alpha \iota 114$ superum caelestia templa / Quae colitis 127-128, odnosnom s namjernim značenjem: $\Delta$ iòs vóov $\dot{\xi} \xi \alpha \pi \alpha \phi i ́ \sigma \kappa \omega v 537$ quo falleret arte Tonantem 599 ili vremenskom:

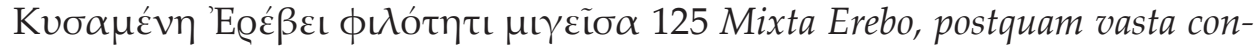
cepit in alvo 139. Zamanja upotrebljava i finitne glagolske oblike poput se-

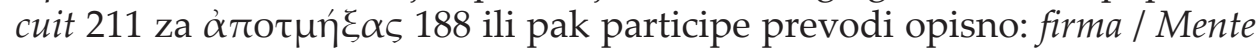
187-188 za $\theta \alpha \varrho \sigma \eta ́ \sigma \alpha \varsigma 168$.

Još su jedan prevoditeljski izazov pri prevođenju s grčkoga na latinski čestice kojima je grčki jezik osobito bogat. U prva 103 stiha Teogonije nalazimo 44 čestice u grčkome tekstu, od čega 28 puta česticu $\delta \varepsilon ́$. U odgovarajućemu dijelu latinskoga teksta (stihovi 1-114) nalazimo samo sedam čestica, što ne znači nužno da je Zamanja izbjegavao prevoditi čestice, nego da ih nije prevodio isključivo česticama. ${ }^{16}$ Kao primjer Zamanjinih prevoditeljskih rješenja pri prevođenju čestica prikazat ćemo čestice u odlomku od 167. do 177. stiha Teogonije te Zamanjina prijevodna rješenja. Zamanja uopće ne prevodi čestice u sljedećim primjerima: $\gamma \dot{\alpha} \varrho 167, \delta$ ' ă $\propto \alpha 168$,

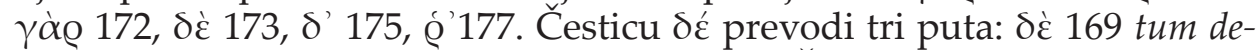

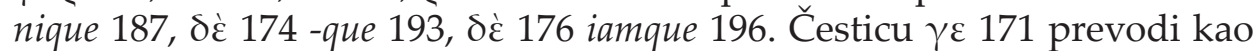
enim 190. Od deset čestica u grčkome tekstu prevedene su četiri. I u ostatku teksta prisutno je nastojanje da se čestice ne prevode. Povezano s prevođenjem čestice $\delta \varepsilon ́$ dodajemo i $\delta$ ' 188 quin 210. Ta grčka čestica može imati suprotno i sastavno značenje te može, između ostaloga, uvoditi objašnjenja, pojavljivati se u nabrajanjima ili prijelazima te označavati uzročno-posljedičnu vezu. ${ }^{17}$ Riječi su kojima je Zamanja prevodi veznici, čestice i pri-

16 Nisu uzete u obzir modalne čestice koje se moraju pojaviti uz optativ, npr. $\kappa \varepsilon v$.

17 Prema natuknici u Liddell-Scottovu rječniku dostupnome na Logeionu. 
lozi. Oni služe povezivanju: sastavni veznik -que (ingenti gavisa est pectore Terra, / Insidiasque parans occulta in sede locavit / Audacem gnatum 192-194) ili nadovezivanju jedne radnje na drugu (metus irruit ingens / Omnibus attonitis monitu. tum denique firma / Mente vafer Saturnus ita est sua dicta sequutus. 186-188, Dat falcem ingentem, multo simul instruit astu. / Iamque aderat Caelus... 195-196). Zamanji nije bilo važno da čestice uvijek prevodi česticama, nego da, ako ih prevede, odabere riječi kojima će postići ono što se česticama postiže u grčkome izvorniku: koherentan, povezan tekst u kojemu se teme elegantno nadovezuju jedna na drugu. Napomenimo ovdje da Zamanja ne upotrebljava uvijek ista rješenja te se npr. česticom scilicet koristi

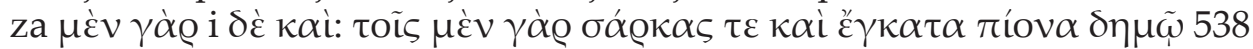

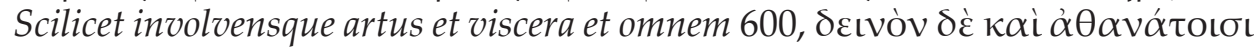

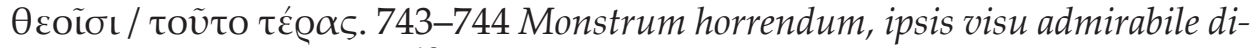
vis / Scilicet est. 825-826. ${ }^{18}$

Posljednji je problem pri prevođenju s grčkoga na latinski koji ćemo istaknuti prevođenje složenica. Uporaba složenica bila je važna osobina pjesničkoga stila još u indoeuropskome prajeziku (West 2007:79-81). Mnogi su Homerovi i Hesiodovi epiteti složenice, ali za razliku od grčkoga, latinski nije bio osobito produktivan $u$ tvorbi složenica te je njihovo prevođenje poseban izazov prevoditeljima (v. Fruyt 2002). Pridjevske složenice važan su stilski element u Teogoniji. Među njima su vrlo česte posvojne složenice koje su egzocentrične, tj. opisuju nešto izvan same složenice, npr. brzonogi opisuje onoga koji ima brze noge. ${ }^{19}$ Budući da se djelo sastoji od niza genealogija i kataloga raznih božanstava (v. Westov prikaz strukture djela u Hesiod 1966:16-18), uz njihova imena očekujemo epitete kao standardno obilježje epike (v. npr. West 2007:83-85).

Zamanja se u prijevodu Teogonije razmjerno rijetko koristi latinskim slo-

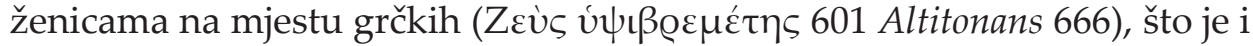
očekivano jer je u latinskome imao manje složenica na raspolaganju. Ipak, nikako mu se ne može predbaciti slabo poznavanje latinskoga rječnika. U

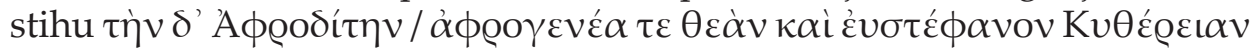
195-196 illam Aphroditen, / Spumigenamque deam, et Cytherean serta gerentem 221-222 upotrebljava Venerin epitet spumigena, sačuvan samo na jednome mjestu u rimskoj književnosti, u djelu Marcijana Kapele (9.915). Za izraz

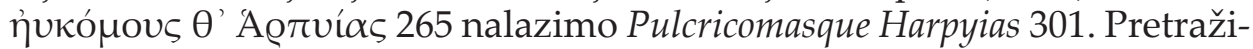
vanjem digitalnih zbirka Musisque Deoque i Poeti d'Italia utvrđeno je da pri-

18 Kaí ovdje nije upotrijebljeno kao veznik, nego kao emfatična čestica.

19 Za razliku od endocentričnih složenica koje opisuju jedan od elemenata složenice, npr. dvosjed ili trosjed opisuju vrstu sjedala, a ne nekoga tko taj predmet posjeduje. 
djev pulcricomus nije posvjedočen ni u korpusu antičke književnosti ni u korpusu renesansne talijanske poezije. ${ }^{20}$ Moguće je da je Zamanja taj pridjev preuzeo iz Le Clercova proznog prijevoda uz Graeviusovo izdanje grčkoga teksta kojim se služio (Hesiod 1701). ${ }^{21}$

Kad pri prevođenju ne uspijeva naći već postojeću latinsku istovrijednicu, Zamanja u prevođenju složenica nastoji zadržati barem dio značenja složenice iz izvornika. Jedna je od njegovih tehnika pri prevođenju riječi za koje ne uspijeva pronaći latinsku istovrijednicu uporaba ablativa svoj-

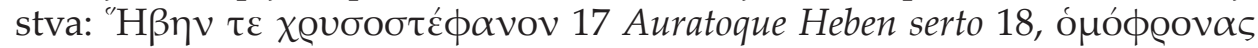

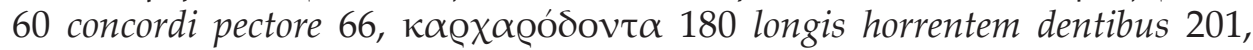

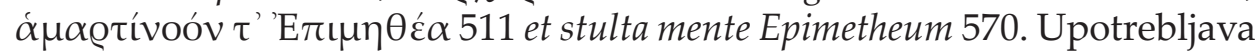

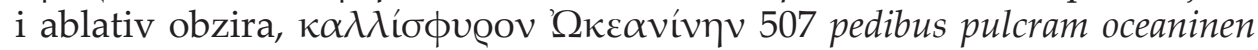
565 te akuzativ obzira, sintaktičku posuđenicu iz grčkoga tipičnu za neo-

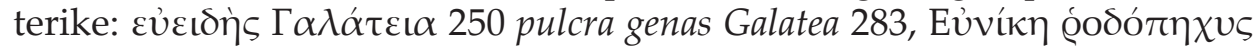

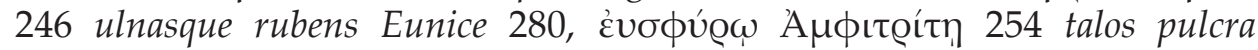

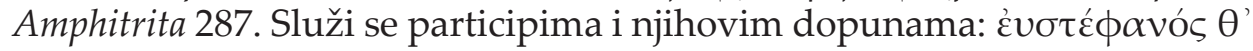

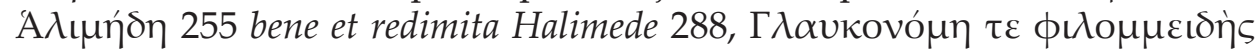
256 Glauconome risu gaudens 289. Neke su složenice potpuno preoblikova-

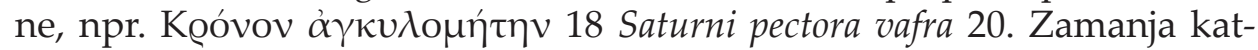

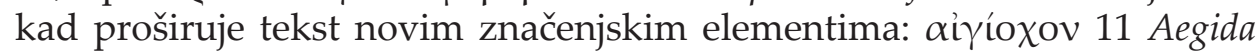

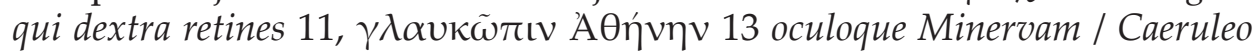

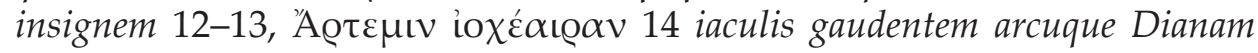

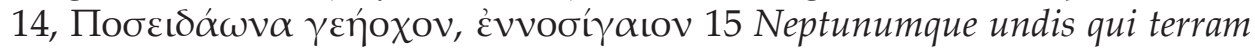

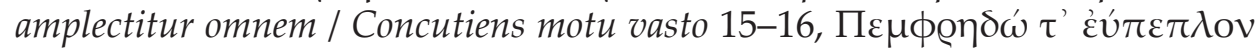

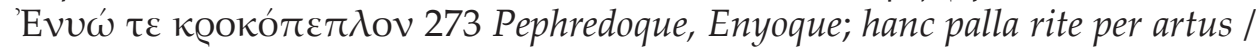
Fulgenti, hanc croceo laetam velamine 308-309.

Katkad zadržava samo jedan značenjski element složenice, a drugi iz-

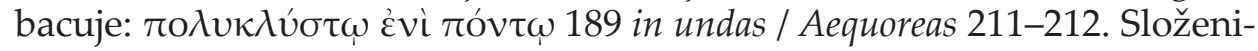

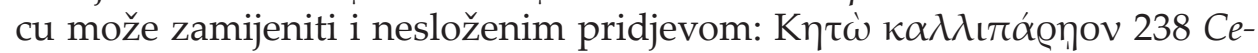

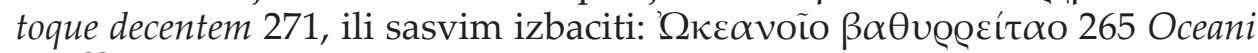

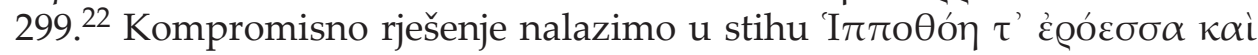

20 Za pretraživanje talijanske renesansne poezije na latinskome upotrijebljena je zbirka Poeti d' Italia.

21 Pojavljuje se i u proznome djelu Historia deorum gentilium talijanskoga humanista Lilija Gregorija Giraldija iz 1548., također uz Harpije (pulchricomas Harpyas). Knjiga je dostupna na stranicama Austrijske akademije znanosti (Österreichische Akademie der Wissenschaften) na https://www.oeaw.ac.at/kal/mythos/. Zamanja spominje Giraldija u predgovoru (Zamanja 1785:XI, XIV). Pridjev se pojavljuje i u Zamanjinu epu Jeka (1.2.136), tiskanome 1764. Uporabu toga teksta smatramo odrazom Zamanjina osobitog zanimanja za mitologiju.

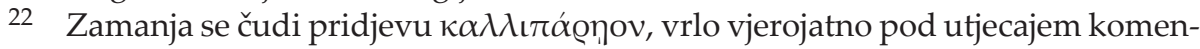




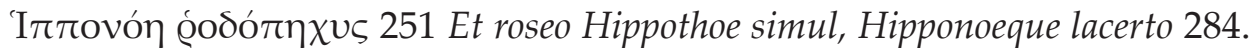
Zamanja prvi epitet izbacuje, a drugi proširuje na obje imenice. Le Clerc ovdje donosi Hippothoëque amabilis, et Hipponoë roseis lacertis praedita, što izborom riječi podsjeća na Zamanju.

\subsection{Još neke opaske o izboru riječi prijevoda}

Iako je o Zamanjinu izboru riječi već bilo govora u prethodnim poglavljima, dodajemo još nekoliko primjera vrijednih spomena. Zamanja dokazuje poznavanje klasičnih latinskih riječi pridjevom anxifer 113, koji se u rimskoj književnosti pojavljuje samo dvaput, oba puta kod Cicerona (Cic. Div. 1, 13, 22; Tusc. 2, 9, 21) te poetskom uporabom riječi marmor u zna-

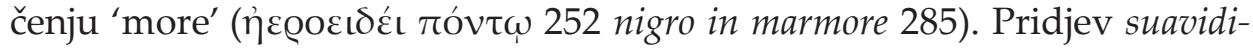
cus 41 posuđen je od Lukrecija $(4,180 ; 4,909)$, a riječ nimbifer $45 \mathrm{u}$ antici su upotrijebili samo Ovidije (P. 4, 8, 60) i Avijen (Arat. 858). Pridjev omnivorus 353 nalazimo u rimskoj književnosti samo kod Plinija Starijega $(25,49)$, a Zamanjina malesuada Fames 256 preuzeta je od Vergilija (Aen. 6, 276).

Što se tiče pročišćavanja dijelova teksta koji bi mogli sablazniti profinjenu publiku, primjerice spominjanje spolnih organa, primjeri inguina pa-

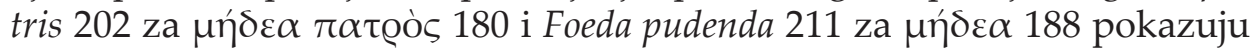
da Zamanja nije bio spreman ići predaleko da pročisti izvornik, ali je birao riječi najvišega registra te dodao pridjev foedus. ${ }^{23} \mathrm{U}$ prethodnome stihu dodao je ceu fama est, što, kao i prethodno navedeno dodavanje pridjeva foedus, objašnjavamo željom da se ogradi od izvornika. Na ovome bi se mjestu izbacivanjem izgubio važan dio priče o smjeni generacija bogova, a priča o Afroditinu rođenju bila bi nejasna. Zamanja u fusnoti polemizira s Le Clercom koji je bio iznio alegorijsko tumačenje stiha potaknuto dvoznačnošću riječi $\mu \tilde{\eta} \delta o s$, što pokazuje da nije bio spreman izmišljati nategnuta objašnjenja samo da ne bi šokirao čitatelje (Hesiod 1785:24-25). Zamanjin prijevod katkad zvuči svečanije od originala: 'E $\lambda \iota \kappa \tilde{\omega} v o \varsigma$ ع̌ $\chi 0 v \sigma \iota v$

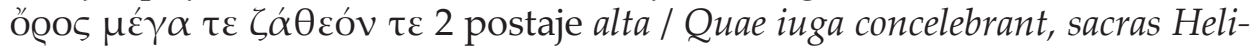
conis et umbras 1-2; osim dodavanja epiteta, čest grčki glagol ह̌ $\chi \omega$ preveden

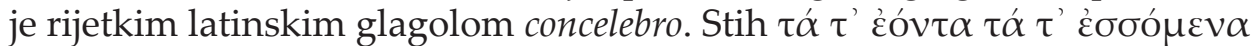
T@ó $\tau$ ' Éóv $\tau \alpha 38$ preveden je Quae sunt, quae venient, quae iam fugere peracta 40, Zamanja tu izbjegava ponavljanje još jednoga čestog glagola sa značenjem 'biti', koji se kod Hesioda pojavljuje tri puta i umjesto toga prevodi s pomoću triju različitih glagola, a u fusnoti navodi sličan Vergilijev stih.

tara uz Le Clercov prijevod u kojemu se smatra da Keta ne može biti lijepa jer su joj kćeri ružne (Hesiod 1701:49, bilješka 238), ali ipak želi ostati vjeran izvorniku, pri čemu primjećuje slobodu grčkih pisaca u uporabi epiteta (Hesiod 1785:35).

23 O potrebi za pročišćavanjem i vjernosti izvorniku govori i Bricko (2002a). 


\section{Zamanjini uzori pri prevođenju Teogonije}

\subsection{Antički uzori}

Već je istaknuto da su izrazi kojima Zamanja prevodi Hesiodove riječi često vrlo slobodan prepjev originala pisan pod utjecajem rimskih pjesnika. U prethodnim odlomcima navele smo riječi koje je Zamanja mogao posuditi samo iz jednoga izvora, npr. Ciceronov hapaks anxifer. Sam je Zamanja u predgovoru djela naveo da želi prijevod približiti Vergiliju. U ovome će se dijelu rada, kako bi se što detaljnije istražili Zamanjini uzori, analizirati klauzule, tj. završetci stihova. Pjesnici koji su pisali na latinskome posuđivali su klauzule od ranijih autora, i to češće nego ostale dijelove stiha. Takva praksa postojala je već u starome Rimu, npr. Vergilije je preuzimao Enijeve klauzule. Kako bi se utvrdio utjecaj autora koje je Zamanja čitao na njegov prijevod Teogonije, klauzule njegova prijevoda uspoređene su s tekstovima u digitalnoj zbirci Musisque Deoque. ${ }^{24}$ Dobivene rezultate usporedile smo s rezultatima ranijega istraživanja o Zamanjinoj Odiseji (Ćosić-Mrgan-Šoštarić 2016). ${ }^{25}$

Od klauzula koje se pojavljuju samo u jednoga autora najveći je broj klauzula iz Ovidijevih Metamorfoza, njih 19. ${ }^{26}$ Osim klauzula iz Metamorfo$z a$ pojavljuju se dvije klauzule iz Fasta, jedna iz Poslanica iz Ponta, dvije iz Ljubavi, ali obje podudarne s klauzulama iz Metamorfoza, te jedna klauzula iz Ljubavnoga umijeća, koja se u Teogoniji pojavljuje dvaput. ${ }^{27}$ Kao drugi se najčešći izvor pojavljuje Silije Italik i njegov ep Punski rat, najveći ep rimske književnosti iz 1. st. poslije Krista. Klauzulama iz Silija Italika kao jedinoga izvora Zamanja se služi 11 puta. ${ }^{28}$ Deset je klauzula iz zbirke Antho-

24 http://mizar.unive.it/mqdq/public/index.

25 Kratice za imena pisaca i djela pisane su prema Oxford Classical Dictionary, 4th edition. Ako ih tamo nema, preuzete su sa stranice Musisque Deoque.

26 atria conplent Ov. Met. 5, 153, gratissima nymphis Ov. Met. 13, 736, praecordia telo Ov. Met. 6, 251, de uulnere, guttae Ov. Met. 2, 360, Thaumas Ov. Met. 12, 303, tegumenque remouit Ov. Met. 1, 674, confinia mundi Ov. Met. 12, 40, dicta probarunt Ov. Met. 8, 616, emisit in auras Ov. Met. 6, 398 / Ov. Met. 15, 220, ardua collo Ov. Met. 1, 730, uoluentia flammas Ov. Met. 7, 109, arma feruntur Ov. Met. 12, 621, sub imum Ov. Met. 4, 162, ora coercet Ov. Met. 6, 226, Thaumantias Iris Ov. Met. 4, 480, ira nocentem Ov. Met. 13, 562, magna uirorum Ov. Met. 11, 557, fronte capillis Ov. Met. 2, 476, per auram Ov. Met. 11, 6.

27 dicta probarunt Ov. Fast. 5, 53, uere iuuentae Ov. Fast. 5, 525, maximus omnes Ov. Pont. 4, 10, 57; nata Cythera Ov. Am. 2, 17, 4 , fronte capillis Ov. Am. 1, 7, 49; thalamoque recepit Ov. Ars am. 2, 407.

28 inde citato Sil. Pun. 12, 171 / Sil. Pun. 13, 750, uiribus acri Sil. Pun. 9, 362, pectore seruat Sil. Pun. 13, 825, pressa furenti Sil. Pun. 1, 545, proferre parabat Sil. Pun. 11, 369, frondentibus umbris Sil. Pun. 12, 354, fragmina montis Sil. Pun. 3, 470, undique portis Sil. Pun. 12, 184, condidit aluo Sil. Pun. 6, 199, ille uirorum Sil. Pun. 7, 58, certare Tonanti Sil. Pun. 10, 54. 
logia Latina, nastale u drugoj polovici 5. ili početkom 6. st. u Africi, koja je imala snažan utjecaj na srednjovjekovno latinsko pjesništvo. ${ }^{29}$ Kao važan se uzor za Zamanjin ep pokazuje i Lukrecije i njegov prirodnoznanstveni ep O prirodi. Devet je klauzula koje su preuzete isključivo iz Lukrecija. ${ }^{30}$ Devet je i klauzula koje Zamanja preuzima iz Eneide. ${ }^{31}$ Prisutne su klauzule i iz ostalih Vergilijevih djela: iz Georgika ih je šest, a jedna je iz Ekloga. ${ }^{32}$ Pet je klauzula iz zbirke Appendix Vergiliana, koja je bila pripisivana Vergiliju. 33 Šest je klauzula iz djela Ciprijana Gala, kršćanskoga pisca s početka 5. st. ${ }^{34}$ Nekoliko je klauzula iz djela Prudencija, kršćanskoga pjesnika iz 4. st. Dvije su klauzule iz Prudencijeva Podrijetla grijeha. Pojavljuju se klauzule i iz polemike s poganstvom Protiv Simaha i predgovora tomu djelu, iz ciklusa Peristephanon i zbirke Cathemerinon. ${ }^{35}$ Četiri su klauzule iz Manilijeva epa $O$ astronomiji. ${ }^{36}$ Četiri su klauzule iz pjesama Paulina iz Nole, kršćanskoga autora iz 4. stoljeća. ${ }^{37}$ Pojavljuju se tri klauzule iz epa Argonau-

29 imitantia uerum Anth. Lat. 521, 1, nomina nymphae Anth. Lat. 742, 20, artibus omnes Anth. Lat. 945, 2, ore renidens Anth. Lat. 485, 150, praemia sorte Anth. Lat. 193, 10, improba rostro Anth. Lat. 733, 7, taedasque iugales Anth. Lat. 742, 52, solatia curis Anth. Lat. 931, 111, inclita proles Anth. Lat. 724, 4, lanugine malas Anth. Lat. 742, 14.

30 mollia membra Lucr. 4, 789 / Lucr. 4, 980, luna nitore Lucr. 5, 768, maximus aether Lucr. 5, 473, terraque creatis Lucr. 2, 940, sublime feruntur Lucr. 4, 133, sola terrae Lucr. 2, 592, lumina cumque Lucr. 2, 114, mutua contra Lucr. 6, 1084, tempore fudit Lucr. 5, 823.

31 clamore resultant Verg. Aen. 5, 150, pulcherrimus omnis Verg. Aen. 4, 141 / Verg. Aen. 7, 55, nomine gentes Verg. Aen. 6, 776 , lacertosque Verg. Aen. 5, 422, aurea clamor Verg. Aen. 5, 140 / Verg. Aen. 11, 832, gurgite lymphas Verg. Aen. 9, 23, desertaque montis Verg. Aen. 8, 191, caerula uexit Verg. Aen. 7, 198, mortalibus almum Verg. Aen. 5, 64.

32 et dulcia furta Verg. G. 4, 346, discordia motu Verg. G. 4, 68, gloria, si quem Verg. G. 4, 6, armentaque laeta Verg. G. 2, 144, spectata labore Verg. G. 1, 197; carmina coepta Verg. Ecl. 8, 12.

33 uertice Olympum App. Verg. Ciris 34, gurgite circum App. Verg. Ciris 452, undique torret App. Verg. Aetna 621, lumina toruo App. Verg. Culex 173, mortalibus almum App. Verg. Ciris 349.

34 dicta secutus Cypr. Gall. Num. 365, fudit ab aluo Cypr. Gall. Gen. 1092, durumque laborem Cypr. Gall. Exod. 755, custodia fida Cypr. Gall. Gen. 1184, genitore creata Cypr. Gall. Gen. 191, coniuge parta Cypr. Gall. Gen. 974.

35 nouimus ipsum Prudent. Ham. 126, aurea dona Prudent. Ham. 925, arce potiti Prudent. C. Symm. 1, 595, triste periculum Prudent. C. Symm. Praef. 1, 66, et almis Prudent. Perist. 5, 287, exul et errans Prudent. Cath. 10, 168.

36 diuumque parentes Manil. Astr. 2, 12, citharaeque sonantis Manil. Astr. 4, 528, torquere lacertis Manil. Astr. 5, 294, corpore natam Manil. Astr. 3, 501.

37 tuentur amore Paul. Nol. Carm. 20, 2, plurima damna Paul. Nol. Carm. 28, 142, cuncta potenti Paul. Nol. Carm. 27, 468, praestat corpore Paul. Nol. Carm. 31, 292. 
tica Valerija Flaka. ${ }^{38}$ Tri su klauzule iz pjesama autora Alcima Avita ${ }^{39}$ i jedna iz dodatka njegovim pjesmama, koja se u Teogoniji pojavljuje dvaput. Riječ je o autoru s prelaska iz 5. na 6. st. Tri se klauzule podudaraju s epom Iohannis autora Koripa iz 6. st., ${ }^{40}$ međutim, riječ je o tekstu koji se smatrao izgubljenim do početka 19. st., pa je upitno je li se Zamanja stvarno njime mogao služiti. Pojavljuje se još jedna klauzula toga autora, ali iz drugoga teksta In laudem Iustini minoris. ${ }^{41}$ Tri su klauzule iz djela Stacija, rimskoga pjesnika iz 1. st. Dvije su klauzule iz zbirke Šume, a jedna iz njegova mitološkog epa Tebaida. ${ }^{42}$ Klaudijanova se djela pojavljuju u trima klauzulama. ${ }^{43}$ Dva su primjera iz Lukanova epa Farsalia. ${ }^{44}$ Dvije su klauzule iz Juvenalovih Satira, ${ }^{45}$ iz epa o životu sv. Martina autora Venancija Fortunata iz 6. st., ${ }^{46}$ iz djela Pjesma protiv Marciona Tertulijana, ranokršćanskoga autora s prelaska iz 2. u 3. st. ${ }^{47}$ Pojavljuju se dvije klauzule iz Avijenova djela Aratove Pojave iz 4. st. $^{48}$ Samo se jedanput u Zamanjinoj Teogoniji pojavljuju Propercije, ${ }^{49}$ Horacije, $^{50}$ Marije Viktor iz 5. st. ${ }^{51}$ i Juvenko, autor iz 4. st. ${ }^{52}$ Taj popis autora pokazuje da je Zamanja dobro poznavao Lukrecija, klasične autore Ovidija i Vergilija, srebrnodobne epičare i kršćanske pisce.

U radu Ćosić i dr. (2016) autorice kronološki navode utjecaje koje su otkrile u Zamanjinu prijevodu Odiseje: Plaut, Lukrecije, Ciceron, Vergilije, Ovidije i drugi elegičari, epičari srebrnoga doba te kršćanski pjesnici. Rezultati dobiveni za Teogoniju ponešto se razlikuju od toga. U Teogoniji nema izraza koji bi upućivali isključivo na Plauta, što objašnjavamo činje-

38 gramina plantis Val. Fl. Argon. 3, 528, Acaste Val. Fl. Argon. 1, 164, condidit antro Val. Fl. Argon. 3, 636.

39 dicere cantu Alc. Avit. Carm. 4, 31, membra uigorem Alc. Avit. Carm. 1, 86, gurgite monstra Alc. Avit. Carm., foedere iunxit Alc. Avit. Carm. App. 7, 18.

40 uoce salutant Coripp. Ioh. 4, 59, omnia lumen Coripp. Ioh. 2, 427, gaudia sensit Coripp. Ioh. 3, 289.

41 candida palmis Coripp. Iust. 2, 50.

42 gurgitis oras Stat. Silv. 2, 1, 194, undique terras Stat. Silv. 3, 2, 69; quis in arma Stat. Theb. 10, 233.

43 stellantis Olympi Claud. Cons. Hon. III 33 / Claud. Carm. min. 31, 21, murmure bellum Claud. Cons. Hon. VI 269, emicat una Claud. Hon. nupt. 323.

44 fatur et acris Lucan. Phars. 2, 323, Tethynque Lucan. Phars. 2, 588.

45 spicula uatis Juv. 13, 79, similis dis Juv. 5, 132.

46 atque profunda Ven. Fort. Mart. 2, 306, peste fugata Ven. Fort. Mart. 3, 88.

47 saeua malorum Tert. Adu. Marc. 4, 7, auribus ultro Tert. Adu. Marc. 4, 228.

48 namque per ipsas, Avien. Arat. 1008, germina florum Avien. Arat. 738.

49 arbiter Orci Prop. 3, 19, 27.

50 et mihi dulces Hor. Sat. 1, 3, 139.

51 munere fecit Mar. Victor Aleth. 3, 732.

52 caelestibus olim Iuvenc. Evang. 1, 183. 
nicom da u Teogoniji, za razliku od Odiseje, nema toliko dijaloga u kojima bi se mogli pojaviti jezični elementi iz komedije. Među klauzulama nema rezultata ni za Cicerona. Možda bi ih bilo da je Ciceron uz Odiseju prevodio i Teogoniju jer se Zamanja poslužio odlomkom iz Ciceronova prijevoda Odiseje i jednostavno ga uklopio u svoj prijevod (Ćosić-Mrgan-Śoštarić 2016). Još je jedna zamjetna razlika u odnosu na izvore za prijevod Odiseje (Ćosić-Mrgan-Šoštarić 2016) u uporabi klauzula iz zbirke Anthologia Latina u prijevodu Teogonije. Moguće je da u Odiseji nije bilo potvrda koje bi upućivale isključivo na to djelo ili da uzorak nije bio statistički relevantan. Od ostalih autora analizirat ćemo samo četvoricu najbolje posvjedočenih kod kojih je najmanja vjerojatnost da je riječ o slučajnosti. Citati iz Ovidijevih djela potvrđeni su i u Zamanjinu prijevodu Odiseje, što Ćosić i dr. smatraju da djelomično izlazi iz očekivanoga zbog Zamanjina isusovačkog obrazovanja jer Ratio studiorum neke Ovidijeve tekstove smatra nepriličnima. Stih iz Ovidijeve zbirke Ljubavno umijeće u kojemu se opisuje Klitemnestrin preljub svakako nije očekivana lektira za jednoga isusovca. Yasmin Haskell nagađa da je $\mathrm{u}$ isusovačkim školama sklonost Ovidiju bila kudikamo veća nego što je propisivala Ratio studiorum (2014a:782). Upada u oči sklonost Siliju Italiku, kojega Ćosić i dr. ne ističu kao omiljenoga autora junačke epike srebrnoga doba. Također, smatramo da, iako razmjerno malen, broj klauzula iz Avijena i Manilija, zajedno s Lukrecijevim klauzulama upućuje na Zamanjinu sklonost didaktičnomu pjesništvu s prirodoslovnim i znanstvenim temama. Na kraju, u Zamanjinu prijevodu Odiseje najzamjetniji je utjecaj Vergilijeve Eneide, što ne čudi s obzirom na to da je riječ o istoj tekstnoj vrsti i najvažnijemu rimskom junačkom epu. Osim toga, Vergilije je isusovcima bio osobito drag autor, pa ne iznenađuje prisutnost klauzula iz njegovih djela i iz onih koja su mu se pripisivala, ali nisu njegova i u Odiseji i u Teogoniji. Sam je autor naveo u predgovoru Odiseje da mu je Vergilije bio važan uzor, pa ne čudi da je od njega posuđivao i klauzule.

\subsection{Zamanja i suvremenici}

Kao što je već navedeno, izdanje grčkoga teksta kojim se Zamanja služio bilo je popraćeno proznim latinskim prijevodom Teogonije iz pera Jeana Le Clerca (Hesiod 1701). Uz već spomenuti pridjev pulcricomus, navodimo još neke poveznice između toga i Zamanjina prijevoda. 


\begin{tabular}{|c|c|c|}
\hline Hesiod & Zamanja & Le Clerc \\
\hline 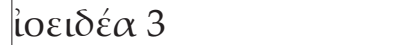 & caerula 3 & caeruleum 3 \\
\hline Xogoùs 7 & choreas 7 & choreas 7 \\
\hline 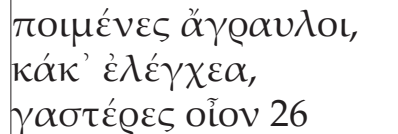 & $\begin{array}{l}\text { Sub dio, o vigiles } \\
\text { pastores, probra } \\
\text { virorum } 27\end{array}$ & $\begin{array}{l}\text { Pastores sub dio } \\
\text { manentes, mala probra } \\
26\end{array}$ \\
\hline 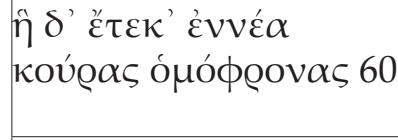 & $\begin{array}{l}\text { Illa novem peperit } \\
\text { concordi pectore } \\
\text { gnatas } 66\end{array}$ & $\begin{array}{l}\text { Ipsa peperit novem } \\
\text { filias concordes } 60\end{array}$ \\
\hline 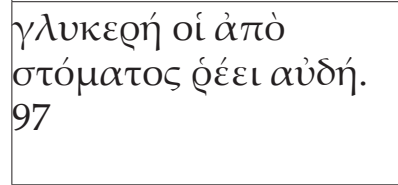 & $\begin{array}{l}\text { Olli vox dulcis fluit } \\
\text { ore, et suavior ipsa } \\
\text { liquitur ambrosia 108- } \\
9\end{array}$ & $\begin{array}{l}\text { Suavis ei ab ore fluit } \\
\text { vox } 97\end{array}$ \\
\hline 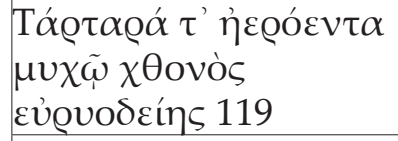 & $\begin{array}{l}\text { Tartaraque immenso } \\
\text { subter tenebrosa } \\
\text { recessu } 133\end{array}$ & $\begin{array}{l}\text { Tartaraque tenebricosa } \\
\text { in recessu terrae } \\
\text { spaciosae } 119\end{array}$ \\
\hline 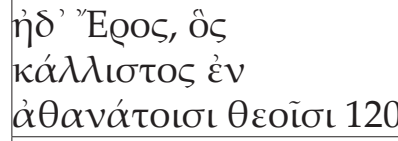 & $\begin{array}{l}\text { Atque Amor, ille deos } \\
\text { inter pulcherrimus } \\
\text { omnes } 134\end{array}$ & $\begin{array}{l}\text { Atque Amor, qui } \\
\text { pulcherrimus inter } \\
\text { immortales deos } 120\end{array}$ \\
\hline 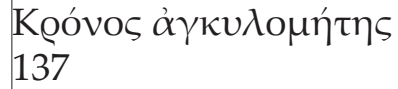 & vafer Saturnus 151 & Saturnus vafer 137 \\
\hline 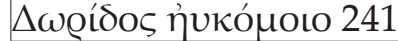 & pulcra e Doride 273 & ex Doride pulcra 241 \\
\hline
\end{tabular}

U tim primjerima postoje podudarnosti u uporabi riječi i sintagma. Smatramo da to ne može biti slučajnost, osobito kad je riječ o rijetkim riječima poput pridjeva vafer. ${ }^{53}$ Vjerojatnije je da se Zamanja povremeno oslanjao na Le Clercov prozni prijevod iako se možda nije uvijek slagao s njegovom interpretacijom Hesioda iznesenom u komentarima.

Postoje podudarnosti između Zamanje i njegovih učitelja. Stih Фó@кvï

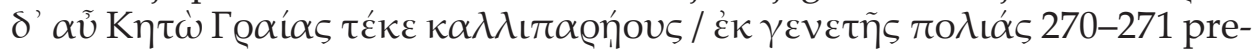
veden je Hinc Graeas Phorcyni enixa est candida Ceto / Canitie insignes aeta-

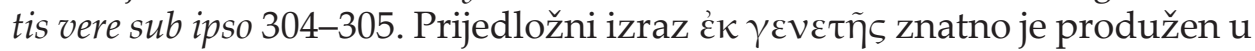
aetatis vere sub ipso, a klauzulu vere sub ipso nalazimo u epigramu Rajmunda Kunića $(9,215,1) .{ }^{54}$ CroALa ovdje navodi Zamanju kao ranijega autora, ali ne treba isključiti mogućnost da mu je bio poznat neobjavljeni Kuni-

53 Logeion navodi da se vafer pojavljuje manje od 50 puta u rimskoj književnosti te ga ne reda po učestalosti (http://logeion.uchicago.edu/vafer).

54 http://croala.ffzg.unizg.hr/cgi-bin/search3t?dbname=croala\&word=vere+sub+ ipso. 
ćev epigram (o Kunićevim epigramima v. Bratičević 2015). Razmjena ideja između dvojice prijatelja sličnoga književnog ukusa svakako ne iznenađuje. Još jedan Zamanjin učitelj Ruđer Bošković izvor je klauzule Nocte nigranti (Zamanjin stih Dicite, qui Terra, qui Caelo, et Nocte nigranti 119), koja je preuzeta iz njegova didaktičnog epa De solis ac lunae defectibus (2,

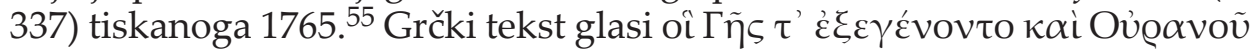

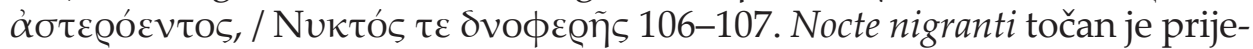

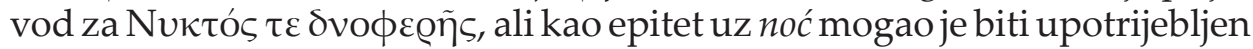
neki češći sinonim poput nigra ili atra umjesto participa rijetkoga glagola nigro, 1.

\section{Zaključak}

Latinski prijevod Teogonije jedan je od prevoditeljskih pothvata našega poznatog latinista Bernarda Zamanje. Njegovo zanimanje za taj arhajski grčki ep ne iznenađuje s obzirom na vrijeme u kojemu Zamanja stvara, a koje je izrazito naklonjeno poučnim epovima i epovima koji se bave poviješću i kulturom naroda. U predgovoru prijevodu dolazi do izražaja širina Zamanjina obrazovanja jer Zamanja pokazuje veliko poznavanje stavova antičkih i kasnijih autora i filozofa o Hesiodu te dobro poznavanje Hesiodova života i djela. U predgovoru Zamanja pokazuje i da je moderni prevoditelj jer se ne zalaže za doslovni prijevod, nego smatra da je zadaća prevoditelja postići prirodan stil u jeziku na koji se prevodi. Pri prevođenju Teogonije s grčkoga na latinski Zamanja se morao suočiti s jezičnim problemima koji su odraz razlika između grčkoga i latinskoga, poput čestote uporabe čestica, razlika u glagolskome sustavu i sklonosti tvorbi složenica. Pri susretu s grčkim česticama Zamanja se uglavnom odlučivao za njihovo potpuno izbacivanje iako je općenito bio sklon proširivanju izvornoga teksta. Jedna od odlika Zamanjina stila bilo je i izbjegavanje ponavljanja. U njegovu je prijevodu proširivanje mnogo češće od skraćivanja i često uključuje izraze posuđene od ranijih pisaca koje je čitao. Zamanja u predgovoru prijevodu ističe želju da Hesiodovu Teogoniju približi duhu latinskoga epskog pjesništva, pa ne čudi da se pritom oslanja na izraze i riječi rimskih klasika. Osobito je izražen utjecaj sljedećih rimskih pisaca: Vergilija, Ovidija, Cicerona, Silija Italika i Lukrecija. Temeljito poznavanje njihova izričaja rezultat je isusovačke naobrazbe koja je osposobila Zamanju da se izražava poput lektirnih pisaca. Što se tiče vremenski bližih autora, tekst možemo dovesti u vezu s prijevodom Jeana Le Clerca te djelima Ruđera Boškovića i Rajmunda Kunića. Zamanja u prijevodu Teogonije odra-

55 http://croala.ffzg.unizg.hr/cgi-bin/search3t?dbname=croalaword=nocte+nigranti. 
žava i neoklasicistički duh vremena te je prijevod mjestimice elegantniji od originala, a od sablažnjivih elemenata autor se diskretno ograđuje.

\section{Literatura}

Appendini, Francesco Maria. 1830. De vita et scriptis Bernardi Zamagnae patricii Rhacusini commentariolum. Zadar: Typis Joannis Demarchi Typographi Gubernialis.

Appendini, Francesco Maria. 2016. Povijesno-kritičke bilješke o starinama, povijesti i književnosti Dubrovčana. Dubrovnik: Matica hrvatska, Ogranak Dubrovnik.

Bitzel, Diane. 1997. Bernardo Zamagna. Navis Aëria: Eine Metamorphose des Lehrgedichts im Zeichen des technischen Fortschritts. Frankfurt am Main: Peter Lang.

Boj žaba i miševa; Natjecanje Homera i Hesioda. 2004. Preveo i priredio Dubravko Škiljan. Zagreb: Izdanja Antibarbarus.

Bowra, Cecil Maurice. 1952. Heroic Poetry. London: Macmillan.

Bratičević, Irena. 2015. Via virtutis: Epigramatski opus Rajmunda Kunića. Zagreb: Ex libris.

Bricko, Marina. 2002a. Naknadno upisana Arkadija: Kunić i Zamanja kao prevodioci Teokrita. Ur. Fališevac, Dunja; Josip Lisac; Darko Novaković. Hrvatska književna baština, sv. 1. Zagreb: Ex libris, 575-593.

Bricko, Marina. 2002b. Zamanja's Translation of Hesiod's Epic Works and Days. Ur. Ferluga Petronio, Fedora. Plurilingvizem v Evropi 18. stoletja. Maribor: Slavistično društvo, 271-281.

Ćosić, Dajana; Matea Mrgan; Petra Šoštarić. 2016. Antički uzori u Džamanjićevu latinskom prijevodu Odiseje. Kroatologija, 7(1), 31-44.

Dixon, Susan. 2006. Between the Real and the Ideal: the Accademia Degli Arcadi and Its Garden in Eighteenth-Century Rome. Newark: University of Delaware Press.

Dowden, Ken. 2011./2014. Telling the Mythology: From Hesiod to the Fifth Century. Ur. Dowden, Ken; Niall Livingstone. A Companion to Greek Mythology. Oxford - Malden Ma - Chichester: Wiley Blackwell, 47-72.

Dukić, Davor. 1998. Grabovčev Cvit razgovora i usmenoepska tradicija. Ur. Strukan, Neven. Fra Filip Grabovac u kontekstu hrvatske kulture. Sinj - Vrlika: Matica hrvatska Sinj - Poglavarstvo grada Vrlike - Matica hrvatska Vrlika, 113-121.

Dukić, Davor. 2002. Poetike hrvatske epike 18. stoljeća. Split: Književni krug.

Dukić, Davor. 2003. Pučka književnost prosvjetiteljstva u Dalmaciji i Dubrovniku. Kolo XIV, 4, 144-165. 
Dukić, Davor. 2007. Andrija Kačić Miošić i književnost Makarskog primorja. Ur. Fališevac, Dunja. Fra Andrija Kačić Miošić i kultura njegova doba. Zagreb: HAZU, 79-90.

Fališevac, Dunja. 2003. Relkovićev "Satir iliti divji čovik« kao demokratsko-prosvjetiteljski spjev. Kaliopin vrt II. Split: Književni krug.

Fruyt, Michèle. 2002. Constraints and productivity in Latin Nominal Compounding. Transactions of Philological Society, 100, 259-287.

Haskell, Yasmin Annabel. 2003. Loyola's Bees. Oxford - New York: Oxford University Press.

Haskell, Yasmin Annabel. 2010. Practicing What They Preach: Vergil and the Jesuits. Ur. Farrell, Joseph; Michael Putnam. A Companion to Vergil's Aeneid and its Tradition. Chichester - Malden MA: Wiley-Blackwell, 203-216.

Haskell, Yasmin Annabel. 2014a. The Passion(s) of Jesuit Latin. Ur. Ford, Philip; Jan Bloemendal; Charles Fantazzi. Brill's Encyclopaedia of the NeoLatin World: Macropedia. Leiden - Boston: Brill, 775-788.

Haskell, Yasmin Annabel. 2014b. The Vineyard of Verse: The State of Scholarship on Latin Poetry of the Old Society of Jesus. Journal of Jesuit Studies 1, 26-46.

Hesiod. 1701. Hesiodi Ascraei quae extant ex recensione Joannis Georgii Graevii Cum ejusdem Animadversionibus et Notis auctioribus. Accedit Commentarius nunc primum editus Joannis Clerici, Et Notae variorum, scilicet Josephi Scaligeri, Danielis Heinsii, Francisci Guieti, et Stephani Clerici, ac Danielis Heinsii Introductio in Doctrinam Operum et Dierum, Nec non Index Georgii Pasoris. Amstelodami: Apud G. Gallet, Praefectum Typographiae Huguetanorum.

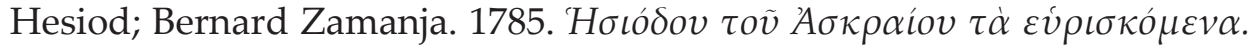
Hesiodi Ascraei opera omnia. Parma: Ex regio Parmensi Typographio.

Hesiod. 1966. Theogony. Ur. West, Martin Litchfield. Oxford: Clarendon Press.

Hesiod. 1999. Theogony, Works and Days. Ur. West, Martin Litchfield. Oxford: Oxford University Press.

Hesiod. 2006. Theogony, Works and Days, Testimonia. Ur. i prev. Most, Glenn W. Cambridge - London: Harvard University Press.

Irmscher, Johannes. 2006. Arcadianism. Ur. Landfester, Manfred; Hubert Cancik; Helmut Schneider. Brill's New Pauly: Encyclopedia of the Ancient World. Classical Tradition. Volume 1. Leiden - Boston: Brill, 210-213.

The Jesuit Ratio studiorum of 1599. 1970. Engleski prijevod, uvod i bilješke Allan P. Farrell, S. J. University of Detroit. Washington D. C.: Conference of Major Superiors of Jesuits. 
Kaminski, Thomas. 2007. Neoclassicism. Ur. Kallendorf, Craig W. A Companion to the Classical Tradition. Malden, MA - Oxford - Carlton: Blackwell, 57-71.

Katz, Joshua T.; Katharina Volk. 2000. Mere Bellies?: A New Look at Theogony 26-8. JHS 120, 122-131.

Koning, Hugo H. 2010. Hesiod: The Other Poet. Leiden: Brill.

Korenjak, Martin. 2016. Geschichte der neulateinischen Literatur. Vom Humanismus bis zum Gegenwart. München: C. H. Beck.

Movrin, David. 2010. Fidus interpres - zvest prevajalec: Slike iz dveh tisočletij zgodovine prevajanja. Ljubljana: Društvo slovenskih književnih prevajalcev.

Nelson, Stephanie. 2005. Hesiod. Ur. Foley, John M. A Companion to Ancient Epic. Oxford: Blackwell Publishing Ltd., 330-343.

Pavličić, Pavao. 1987. Kamo spada Reljkovićev Satir. Narodna umjetnost, 24, 1, 133-144.

Reece, Steve T. 2011. Epithets. Ur. Finkelberg, Margalit. The Homer Encyclopedia. Volume I. Malden MA - Oxford - Chichester: Wiley-Blackwell, 257-259.

Rosati, Gianpiero. 2009. The Latin Reception of Hesiod. Ur. Montanari, Franco; Antonios Rengakos; Christos Tsagalis. Brill's Companion to Hesiod. Leiden: Brill, 343-374.

Schlegel, Catherine M. 2006. Introduction to Hesiod. U: Hesiod. Theogony and Works and Days. Ann Arbor: University of Michigan Press, 1-10.

Snell, Bruno. 2011. Arkadien, die Entdeckung einer geistigen Landschaft. U: Die Entdeckung des Geistes: Studien zur Entstehung des europäischen Denkens bei den Griechen. 9. Auflage. Göttingen: Vandenhoeck \& Ruprecht, 257-274. Izvorno objavljeno u Antike und Abendland, 1944, 1, $26-41$.

Sowerby, Robin. 2006. The Augustan Art of Poetry: Augustan Translation of the Classics. Oxford: Oxford University Press.

Šonje, Šimun. 1975. Osobitosti Homerova epskog stila u Odiseji Bernarda Džamanjića (Zamanje). Dubrovnik, 1, 24-52.

Šoštarić, Petra. 2013. Ulisse, condottiero di uomini: innovazione nella traduzione di Zamagna delle formule omeriche. Ur. Pellizer, Ezio. Ulisse per sempre: Miturgie omeriche e cultura mediterranea: rendiconti. Trst: Editreg, 83-93.

Tatti, Silvia. 2012. I Giuochi olimpici in Arcadia. Atti e Memorie dell' Arcadia, 1, 63-80.

Toohey, Peter. 1996. Epic Lessons - An Introduction to Ancient Didactic Poetry. London - New York: Routledge.

West, Martin Litchfield. 2007. Indo-European Poetry and Myth. Oxford: Oxford University Press. 
Wiebenson, Dora. 1964. Subjects from Homer's Iliad in Neoclassical Art. The Art Bulletin, 46(1), 23-37.

Woodard, Roger D. 2009. Hesiod and the Greek Myth. Ur. Woodard, Roger D. The Cambridge Companion to Greek Mithology. Cambridge: Cambridge University Press, 83-165.

Zamanja, Bernard; Rajmund Kunić. 1764. Bernardi Zamagnae e Societate Jesu Echo libri duo. Selecta Graecorum carmina versa Latine a Raymundo Cunichio ex eadem Societate. Rim: Ex typographia Francisci Bizzarini Komarek.

Zamanja, Bernard. 1776. Scutum Herculis Hesiodi Ascraei Latine versum a Bernardo Zamagna. Siena: Apud Vincentii Pazzinii Carlii filios.

Zamanja, Bernard. 1777. Homeri Odyssea Latinis versibus expressa a Bernardo Zamagna Ragusino. Siena: Excudebant fratres Pazzinii Carlii.

Zamanja, Bernard. 1780. Opera et dies ac Scutum Herculis carmina Hesiodi Ascraei Latinis versibus expressa a Bernardo Zamagna Ragusino. Milano: Typis imperialis monasterii s. Ambrosii majoris.

Zamanja, Bernard. 1785. Hesiodi opera omnia Latinis versibus expressa atque illustrata a Bernardo Zamagna Ragusino. Parma: Ex regio Parmensi Typographio.

\section{Mrežni izvori}

Crane, Gregory. Ur. Perseus Digital Library. http://www.perseus.tufts.edu (pristupljeno 30. 9. 2018.)

Croatiae auctores Latini bibliotheca electronica: CroALa.

http://croala.ffzg.unizg.hr/ (pristupljeno 2. 2. 2019.)

Digitalne zbirke Nacionalne i sveučilišne knjižnice u Zagrebu. https://digitalna.nsk.hr/pb/?object=info\&id=10835 (pristupljeno 8. 7. 2019.)

Logeion.

http://logeion.uchicago.edu/ (pristupljeno 1. 12. 2018.)

Musisque Deoque.

http://mizar.unive.it/mqdq/public/ (pristupljeno 1. 12. 2018.)

Österreichische Nationalbibliothek.

http://digital.onb.ac.at (pristupljeno 1. 12. 2018.)

Poeti d'Italia.

http://mizar.unive.it/poetiditalia/public/ (pristupljeno 1. 12. 2018.)

Österreichische Akademie der Wissenschaften.

https://www.oeaw.ac.at/kal/mythos/ (pristupljeno 1. 12. 2018.) 
Zamanja, Bernard u Hrvatska enciklopedija.

http://www.enciklopedija.hr/Natuknica.aspx?ID=66791 (pristupljeno 1. 12. 2018.)

\title{
Zamanja's Translation of Hesiod's Theogony
}

\begin{abstract}
In this paper Zamanja's verse translation of Hesiod's Theogony is analyzed and set into context. Zamanja's choice of Hesiod relates to the characteristics of the period in which the text was translated: didactic epic was a popular genre in the 18th century. The influence of Jesuit education on Zamanja's work is shown. The relation between Zamanja and Hesiod is analyzed and the information that Zamanja gives about Hesiod in the introduction to his translation is presented. The main problems of translating from Greek into Latin like particles and compounds are discussed, together with an analysis of Zamanja's approach and translation technique. The authors try to determine who were Zamanja's role models in composing the Latin text by analyzing specific words, especially those unwarranted by the original, and clausulae. These are compared to the sources available in digital archives of Latin texts, mainly Musisque Deoque.
\end{abstract}

Ključne riječi: Hesiod, Zamanja, prevođenje s grčkoga na latinski, hrvatski latinizam

Keywords: Hesiod, Zamagna, Greek-to-Latin translation, Croatian neo-Latin literature 
